\title{
Multi-Criteria Decision-Making Approach for the Sustainable Autonomous Energy Generation through Renewable Sources. Studying Zakynthos Island in Greece
}

\author{
Ioannis Vardopoulos \\ Department of Home Economics and Ecology, School of Environment \\ Geography and Applied Economics, Harokopio University \\ E-mail: ivardopoulos@ post.com
}

Received: November 7, 2017 Accepted: November 21, 2017

doi:10.5296/emsd.v7i1.12110 URL: https://doi.org/10.5296/emsd.v7i1.12110

\begin{abstract}
Nowadays, energy demand is considered a notable world problem. The purpose of this study is to define, document and finally select an option of only one renewable energy source system, as to which is considered the most suitable solution from an environmental, social and economic point of view, for the energy independence of Zakynthos Island in Greece. This study examines the following alternatives; Biofuels Production Station, Geothermal Power Station, Hydroelectric Power Station, Solar Power Station and Wind Power Station. In order to determine the optimal renewable energy source, a multi-criteria decision-making approach is followed. The three pillars of sustainability, namely, the environment, the economy and the society, were used as the primary criteria in the context of the under determination goal. A significant number of environmental, economic and social sub-criteria were also developed and were subject to weight evaluation using both pairwise comparison and evaluation through structured interviews. Results, with regard to the delimitations set for the scope of the current study, indicate that solar energy source system is the optimal sustainable alternative.
\end{abstract}

Keywords: Sustainability, Renewable energy sources, Multi-criteria decision-analysis

\section{Introduction}

Today, energy demand is considered a notable world problem. Recent utilization of renewable energy sources (RESs), aimes not only towards oil independence, financially speaking, but also protecting the environment from the unrestrained human usage. RESs 
should at some point overcome the environmental, social, economic, technical and institutional obstacles raised. However, the environmental impact of RESs has more or less been identified. The intricate RESs matter makes the selection between the available different options a multidimensional project (Tsoutsos, Drandaki, Frantzeskaki, Iosifidis \& Kiosses, 2009). The purpose of this study is to define, document and finally select an option of only one RES, as to which is considered the most suitable solution from an environmental, social and economic point of view, for the energy independence of Zakynthos Island in Greece.

Energy plans and designs intend to determine the optimal combination of energy sources in order to satisfy a given energy demand, and so the competent European Union bodies have, already since 1996, shown the way towards renewable energy sources issuing the Green Paper. The Green Paper, as a report and discussion document, representing the best EU's proposal for increasing the share of RESs -although remaining uncommitted-, was the first major step towards setting out the objectives and strategy related (European Commission, 1996). Following that, the context for the impairment of adverse effects and risks was set along with the alignment of the Members States in the new order through the White Paper. The 1997 White Paper (European Commission, 1997), as an authoritative "tool of participatory democracy ... not [an] unalterable policy commitment" (Doerr, 1971), intending to inform concisely about the philosophy behind this complex and controversial issue, meant to help towards making a decision for solving the problem by focusing on four parameters: a. Institutionalized incentives and facilities for those who choose to utilize RESs. b. Open up markets to imported RESs. c. Promote the use of renewable energy, especially for public transportation, public lighting and heating and d. Incentivize/motivate energy proofing of buildings and infrastructure. Thus, EU willing to apply green policies and align with the above mentioned contexts, has raised -non legislative- a set of objectives, such as the sustainable management of energy with low greenhouse gas emissions against global warming, the creation of a network for the reliable and low level energy supply losses, the operation of 'free market' and competitiveness aiming at affordable prices for the final recipient, etc (European Commission, 2017a).

The EU is mainly based on imported fuels, a fact that affects its economic welfare, given that it costs over 350 billion euros per year (Vasileiadis, 2015). The EU aims to reduce greenhouse gas emissions by as much as $95 \%$ by 2050 -compared to the emissions of 1990(European Commission, 2011a) using certain techniques such as the improvement of the internal markets function, the development of solidarity in the event of energy crises, the optimization of the trading emissions mechanism, the increase in carbon capture and storage technologies, the development of safeguards regarding nuclear energy, the raising of the awareness among EU citizens on energy issues, etc (Ageridis et al., 2011).

On 11 May 1998, the Council of Energy Ministers of the EU discussed in Brussels resulting the White Paper on renewable energy systems, which constitutes a guide for the necessary measures in order for the European Member States to develop and use renewable energy systems in the European area (Koronaios, 2012). With a view to the next 20-30 years, the Green Paper drew attention to the structural weaknesses and the geopolitical, social and environmental disadvantages of the EU's energy supply in 2000, particularly with regard to 
the commitments made by Europe's stakeholders under the Kyoto Protocol (European Commission, 2011b). More specifically the main objectives were: a. Climate change mitigation, b. Restriction of the dependence on imported hydrocarbons, c. Sustainable development, innovation and employment (European Commission, 2007) and d. in an effort to achieve through energy supply safety the sustainability goals set, the implementation of the $20 / 20 / 20$ project, which aims to reduce gas emissions by $20 \%$ compared with the emissions back in 1990 while saving energy and improving energy efficiency by 20\% (European Commission, 2008). A long-term and ambitious European energy policy should, after all, be based on the following axis: sustainability, supply safety and competitiveness (European Commission, 2007).

According to the European Directives, such as the 2009/28/EC Directive, some quantitative objectives -non binding- have been set towards 2020, which, among others, mainly include a $20 \%$ reduction in greenhouse gas emissions -in relation to the pre-industrial period values-, measures towards $20 \%$ energy coming from renewable sources and $20 \%$ energy efficiency (European Commission, 2017b). Accordingly, EU recognizing that these objectives are not enough for the overall sustainable balance of the already strained environment, has set even higher objectives towards 2030 which include, among others $20 \%$ (40\% overall) greenhouse gas emissions reduction, $7 \%$ further (20\% total) energy efficiency using renewable energy sources, $10 \%$ (30\% in total) in energy efficiency improvement, and reach a point where able to deliver $15 \%$ of the total produced energy (thus including the $40 \%$ energy coming from renewable energy sources) to other countries within or outside Europe. Respectively, even more ambitious are the objectives set towards 2050, being aware of the intense issue of climate change, aiming 50\% greenhouse gas emissions reduction (European Commission, 2017b).

For the above mentioned guidelines, some binding and some other non-binding content have been compiled to Member States. Some of them are: a) 2001/77/EC Directive regarding the national objectives for each Member State towards 2020, b) 2003/30/EC Directive concerning promoting biofuels towards replacing oil -at least for public transportation- c) 2004/8/EC Directive concerning the encouragement towards multifaceted energy production using conventional and renewable energy sources, etc. (European Commission, 2017b).

The first essential legislative samples of the Greek state, were the enactment of the No 2773 Greek Law in 1999 and No 3468 Greek Law later in 2006, with which some national objectives were set, such as manage $20 \%$ of energy production -of domestic consumptionout of RESs until 2010 and 30\% until 2020, the institutionalization of licensing, the authorization for hybrid energy production solutions on islands -not connected to the main network-, the pricing rank set dependent on the source of electricity, and more (Greek Ministry of Environment and Energy, 2017). No 3851 Greek Law in 2010 regarding further development of RESs in order to address climate change, along with similar provisions under the auspices of the Greek Ministry, actually incorporate the 2009/28/EC Directive into the national legislation and together with the earlier No 3734 Greek Law in 2009 set the following objectives towards 2020: a. $40 \%$ penetration of renewable energy in gross electricity consumption b. $20 \%$ share of RESs in gross electricity consumption for heating 
and cooling and c. $10 \%$ share of RESs in the transport sector. Including also issues related to simplifying licensing procedures for RESs installations and the creation of a renewable energy agency $d$. the exploitation of natural resources in Greece, for renewable energy production, e. drawing green growth strategies and plans, etc. (Greek Ministry of Environment and Energy, 2017).

The national 2020 targets regarding renewable energy production were set to meet $15 \mathrm{GW}$ energy production from RESs and more specifically $7.5 \mathrm{GW}$ out of wind power systems, $2.5 \mathrm{GW}$ out of solar power systems and $4.7 \mathrm{GW}$ hydroelectric systems (Greek Ministry of Environment and Energy, 2009; Greek Ministry of Environment and Energy, 2010). This target, according to recent ministerial estimations, will not be achieved unless an extensive orientation on wind power systems is not applied, particularly on the Aegean Islands, wherein the greatest potential actually exists (Greek Ministry of Environment and Energy, 2014).

Energy production in Greece primarily comes from thermoelectric power station located in the Northern part of the county mainly due to domestic lignite deposits. The 2016 energy balance shows that $60 \%$ of the total produced energy is out of lignite, which is considered a highly polluting fuel (Hellenic Statistical Authority, 2017a).

Environmental protection, as a high priority objective of the Greek State along with the strategy towards resolving the country's energy needs, is achieved through the legislative initiatives following certain simple guidelines:

- The use of various energy sources

- Oil and gas transportation pipeline construction using international networks

- Efficient domestic energy sources consumption

- Dependence on high risk imported energy sources

- Renewable energy systems development

- Clean energy technology development

- Liberalization of the energy market

- Private investments on energy systems promotion

- Energy efficiency systems

\section{Zakynthos Island Physiognomy}

In an attempt to plan and implement a sustainability proposal in a certain place, what should one researcher look for? What special characteristics should one measure and take under consideration? Do only economic data, or environmental needs and sociopolitical circumstances matter? This is an important aspect that researchers are constantly facing in their attempt to offer in the academic community and the society solutions on the major issues that cause global concern.

In this context, this research approaches a place, as a case study with respect to those characteristics that constitute its physiognomy (Mitoula, Theodoropoulou, Karnabos \& Apostolopoulos, 2012). Certain characteristics that are included in fields from all three pillars of sustainability, namely society, economy and the environment are recorded, analyzed and investigated (Mitoula, 2007). 


\section{MInstitute Macrothink $_{\text {Intion }}$}

Due to specific natural and cultural characteristics, the area under study, Zakynthos Island of Greece, is internationally known.

Zakynthos lies in the eastern part of the Ionian Sea, around 9.5 miles northwest of the Greek mainland. Zakynthos is the southernmost of the main group of the Ionian Islands. The island is approximately 25 miles long and 12 miles wide. The coastline is about 76 miles long. The island's area reaches 410 square kilometers and the population is 40,564 inhabitants according to the latest census (Hellenic Statistical Authority, 2017b). Zakynthos is notably large and is sorted in the 11th position in land terms of all the other 227 inhabited Greek Islands.

As shown from the Hellenic Statistical Authority, half of the total area of the island is farmland and $10 \%$ pastures, while -despite the frequent and extensive fires- $35 \%$ are forests (Hellenic Statistical Authority, 2017c).

Regarding the infrastructure of the island, a road network of nearly 95 kilometers (major roads) exists, two main ports that connect the island with central Greece and Italy operate, as well as many other smaller harbors and marinas. On the island, a national airport exists which hosts flights mainly of medium-sized aircraft.

Geologically, Zakynthos is located exactly in-between two geotectonic zones of the Ionian, that is considered to be overthrusted to the Paxos zone, and the Pre-Apulia (Greece's mainland side) (Aubouin and Dercourt, 1962) making the island with numerous of either mild or intense earthquakes, quite active.

The limestone formations of Cretaceous, Eocene, Oligocene are considered the most important water recipients in Zakynthos. But the water in many cases near the coasts suffers from salinization due to the low levels of the aquifer (2-3 meters from the sea level). Into the geological formations in Zakynthos, three major aquifers are developed. a) In the east, the restricted aquifer in Neogene deposits of Kypseli Unit, b) the unique karstic source of carbonate formations located west in Keri Lake and c) in the central-east the unconfined alluvial aquifer (Megalovasilis, Kalimeris, Founda \& Giannakopoulos, 2011; Megalovasilis, 2014).

According to the Greek Ministry of Agriculture orthophoto maps, the mountainous Zakynthos flora has the structure of a degraded Mediterranean Forest. In forests, overgrazing does not occur, although studies regarding the grazing capacity were not found. No logging occurs. The few crops cultivated in the upland area are mainly raisings, grapes and wheat. The last 30 years, a reduction of pasture in favor to crops is observed. The principal agricultural products are olive oil, grapes, currants and citrus fruits. The Island's flora belongs to the Mediterranean ecosystems (Tsirika, Skoufas \& Haritonidis, 2007).

Regarding Zakynthos fauna, inhabit all kinds of pets, rabbits, ferrets and the grey squirrels. Numerous species of insects exist. The birds that inhabit the island are distinguished depending on where their nest is made. Zakynthos owns two very important inhabitants of rare marine species protected by international conventions and domestic Law's. The sea turtle Caretta Caretta and the Mediterranean Monk Seal Monachus Monachus. The National Marine 


\section{Macrothink}

Park of Zakynthos, an 135.000 ha area, was established by Law in 1999, the first of its kind in Greece. In Zakynthos have been recorded three wildlife sanctuaries, an Area of Conservation, and a zone protected by the Special Protected Areas Law (Greek Official Gazette 906/D/22.12.1999). Laganas Bay (nesting beach) has been characterized as a 'Biogenetic Reserve' (Council of Europe). Furthermore, two more special areas of conservation of about 65,000 ha and two more special protection areas of about 215.000 ha have been identified. Finally, aligning with the 92/43/EC Directive regarding the conservation of natural habitats and wild flora and fauna, Zakynthos state has legislated networks of protected areas of Natura 2000 project (Figure 1) (National Marine Park of Zakynthos, 2017).

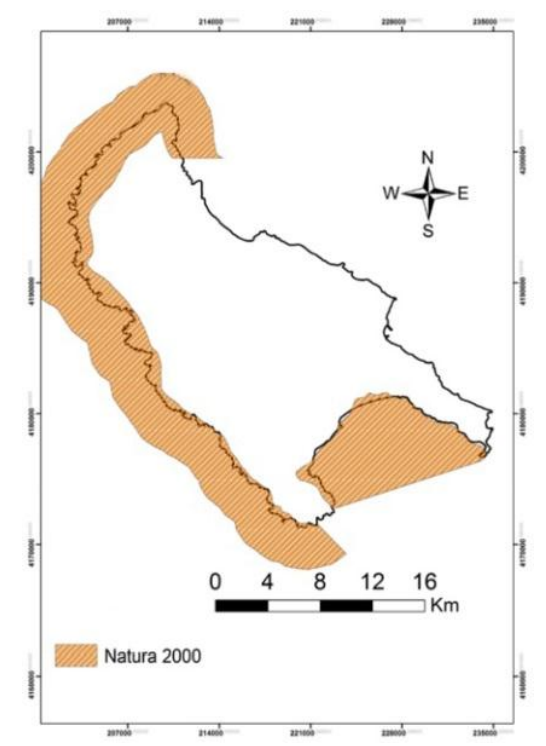

Figure 1. Zakynthos Natura 2000 under Legal Protection Areas Map (Chatzipanagiotou, Oikonomidis \& Voudouris, 2015)

The island is situated in the thermo-Mediterranean Bioclimatic Zone, which represents hot and dry climate. The climate of the mountainous part of Zakynthos is Mediterranean, mild, without extreme values of temperature. Conditions of still air appear $36 \%$ of the time of a year and maximum wind speed can reach up to 8 Beaufort. The prevalent winds are northern and southern. Winds are stronger from November to February. The temperature rarely drops below $1^{\circ}$ or $2^{\circ}$ Celsius degrees. Moisture in November reaches $78 \%$, while in July reaches up to 56\%. (Kalimeris, Founda, Giannakopoulos \& Pierros, 2011; Vardopoulos, 2017; Hellenic National Meteorological Service, 2017). According to rainfall stations in Zakynthos, rain reaches an average concentration of $830 \mathrm{~mm}$, considering the annual distribution quite satisfactory. Lastly, according to the bioclimatic map of Greece, the climate in lowland Zakynthos is weak thermo-Mediterranean. More detailed studies of rainfall in Zakynthos (Megalovasilis, Kalimeris, Founda \& Giannakopoulos, 2011) have come to realize a significant loss of about $22 \%$ of available water in 4 decades.

Also notable is that the island records a significant cultural heritage with a number of archaeological sites and monuments (indicatively: Konomos, 1964; De-Viazi, Konomos \& 


\section{MInstitute Macrothink $_{\text {Ins }}$}

Tsourakis, 1968; Petris, 1978; Zivas, 1984; Solman and Cox, 1991; Mylona, 1998; Whittaker, 2002; Tzivara, 2009; Sammon \& Hirst, 2014; Zervanos, 2015).

According to recent studies of possible sitting renewable energy systems, which implement criteria set by the Law (restrictions) and gradually remove (buffer tool) the conflicting areas of infrastructure, housing, production, cultural sites and environmentally protected areas, it appears that approximately 100 areas are suitable, of a total 60 square kilometer surface (Giannakopoulos, 2015). According to recent studies this amount of land is enough to host RES infrastructure to cover the energy needs of the island (indicatively: Amatya et al., 2015; Andrews, Dewey-Mattia, Schechtman and Mayr, 2015; Trainor, McDonald and Fargione, 2016; Swain, Lovering, Blomqvist, Nordhaus and Hernandez, 2015).

According to the Hellenic Independent Power Transmission Operator (2017a), for the energy needs of Zakynthos Island underwater electricity transmission lines are connected $(150 \mathrm{kV}$ high voltage cables) with the neighboring Cephalonia Island and with the national interconnected system in the Prefecture of Ilia. A $150 \mathrm{kV}$ single-circuit transmission network runs through the island, which effectively connects the underwater electricity transmission lines with the electricity substation located in the city of the island. Also in the city of the island, a power station with an installed capacity of 27MW operates. The island's energy need as reported from the Hellenic Statistical Authority (2017a) deriving from the energy consumption is about $185.000 \mathrm{kWh}$. At least half of the above mentioned recorded consumption is of commercial use, about one-third of domestic use while public and municipal infrastructure uses about $2 \%$, agriculture about $1 \%$ and industrial about $6 \%$.

Zakynthos economy relies mainly on tourism and the primary sector (Table 1) and constitutes the $0.3 \%$ of GDP (Hellenic Statistical Authority, 2017d). Zakynthos owns rich vegetation, resulting in a significant agricultural production, mainly based on cultivating olive, citrus fruits, raisins, vegetables and grains along with floriculture and wine. However, the agricultural sector contributes $12 \%$ to the income of residents (Hellenic Statistical Authority, 2017d). Important is still considered the stockbreeding sector, with signs of growth along with the beekeeping. The secondary economic sector includes the production of the Zakynthian Nougat, Sesame Seed Candy, Soap and the standardization and processing of the agricultural and stockbreeding products (wineries, cheese industries, etc.). Although in recent years productivity sectors are facing difficulties due to the economic crisis, also important is the production of construction materials (gravel, concrete, etc.) and the cutting and processing of stone, marble, wood (furniture), steel, etc. The services sector of the economy contributes by almost $68 \%$ in local income, including tourism, local services, banks, insurance market, retail and wholesale shops (Hellenic Statistical Authority, 2017d). The significant business activity and development, focusing on the tourism sector, which, besides the fact that sometimes becomes enlarged, is assisted by the globally well-known history, beauties, food, tradition and good weather this land offers combined with the local national airport and the numerous hotels and accommodation infrastructure. (Ithakisios, 1988; Kütting, 2010; Zarkadi, 2009). 
Table 1. Economically Active Population (resident's number) in Zakynthos vs Ionian Islands Region (Hellenic Statistical Authority, 2017d)

\begin{tabular}{|c|c|c|c|c|c|}
\hline \multirow{2}{*}{ Region } & \multicolumn{5}{|c|}{ Economically Active } \\
\cline { 2 - 6 } & \multirow{2}{*}{ Total } & \multicolumn{4}{|c|}{ Employed } \\
\cline { 3 - 6 } & & Total & Primary Sector & Secondary Sector & Tertiary Sector \\
\hline Ionian Islands & 88.693 & 73.350 & 6.898 & 9.852 & 56.392 \\
\hline Zakynthos & 18.271 & 15.206 & 2.158 & 1.756 & 10.992 \\
\hline
\end{tabular}

Consistent with the wider literature (see above), findings from this study suggest that Zakynthos is a unique Island regarding its history and environment (physiognomy), thus sustainability approaches, which are often an issue, with respect to science, much likely to be proposed and implemented, are much likely to fail. Here lies the need -and novelty- for this particular case under study. A multidimensional issue requires a multidisciplinary approach.

\section{Renewable Energy Sources}

RESs are considered those that use natural resources such as sunlight, wind, rain, tides, waves and geothermal energy (Sanz-Bobi, 2014). RESs often provide energy on four key sectors, the electricity production services, cooling and heating systems, the transport sector and the rural services (Ellabban, Abu-Rub \& Blaadjerg, 2014; Papaefthymiou \& Dragoon, 2016; Sørensen, 2004). A brief description of the alternatives examined for the scope of the current research follow.

\subsection{Wind Power}

The wind may be used for operating wind turbines. Modern wind turbines range from about $600 \mathrm{~kW}$ to $5 \mathrm{~kW}$ of the nominal total power, with the most common being the turbines with rated output of 1.5 up to $3 \mathrm{MW}$. The electricity coming from wind is a formula of the wind speed, where as the wind speed escalates the power generated increases (European Wind Energy Association, 2009). Preferred areas are considered those where the winds are strong and stable, such as the coastal and high altitude areas (Sanchez-Lozano, Garcia-Cascales \& Lamata, 2014). Usually, the full-load hours range between $16 \%$ and $60 \%$ annually (Badr, Atallah \& Bayoumi, 2016). Worldwide, the long-term technical potential of wind power is believed to be many times of the total current global energy production (Wiser et al., 2016). Wind power is nowadays extensively used and especially in Europe, China and the USA. Within a decade (2004-2014), wind power has a more than seven-fold increase from 47GW to $370 \mathrm{GW}$ (Global Wind Energy Council, 2017).

Apart from the environmental benefits deriving from using wind energy systems, it is particularly important that this type of energy source can be produced in any location, such as remote villages and islands and contributes towards their energy autonomy. Indicatively, the operation of a 10MW wind farm offers the annual electricity needed by 7.250 households and contributes towards saving about 7.500 tonnes of conventional fuels, thus approximately 900 tonnes of $\mathrm{CO} 2$ are not emitted and 140 job opportunities are created. Due to the existing infrastructure constrains (road conduction, port size, etc.) the most prevalent types of wind turbines for the most islands in Greece are machines with a nominal power of up to $500 \mathrm{KW}$ 
(Kaldellis, 2005). Noteworthy, as Kiziroğlu and Erdogan (2012) highlight regarding wind energy threats to birds is that the available data and estimations reveal that bird death rates by wind turbines compared to other factors are quite low. However, for the establishment of wind energy systems and in order to be undoubtedly bird-friendly it is suggested to be properly sited following recommendations by ornithology observation reports (Kiziroğlu \& Erdogan, 2015; Johnson, Loss, Smallwood \& Erickson, 2016).

According to the recent international academic literature, depending on the installation site and the investment, the initial cost of installing a wind farm ranges circa from $700 € / \mathrm{kW}$ to $1.200 € / \mathrm{kW}$, while the cost for maintenance and operation is annually $25 \%$ (higher cost ratios -up to $90 \%$ - are valid for offshore farms. for onshore farms located in cold-icy or remote areas and not applicable to Greek Islands nominal power wind turbines) of the initial installation cost, thus it ranges from $125 €$ to $300 €$ (Türkay \& Telli, 2011; Breeze, 2016; Chadee \& Clarke, 2017).

\subsection{Solar Power}

Solar Power: Solar energy is energy that is transferred to the earth from the sun. This is a primordial, mild and renewable energy source. The energy of the sun comes from the nuclear fusion reactions to its mass, by converting hydrogen into helium at a rate of 4 billion tons per second. The earth's surface receives, directly and indirectly radiation, which in Europe stands for 50\% of the total (Wang, O'Donnell \& Brandt, 2017). Photovoltaic elements directly convert solar energy into electricity. Photovoltaic systems are very flexible and can cover both low and great electricity needs. The obstacles for spreading the photovoltaic systems use is mainly located in a) their relatively high cost $(4-9 \mathrm{~K} € / \mathrm{kWp}), \mathrm{b})$ the fact that the produced energy(/electricity) is significantly more expensive than the one produced using other renewable energy sources, and c) the huge land exploitation -at least for large power systems(Diakoulaki \& Karangelis, 2007).

According to the Hellenic Energy Regulatory Authority, Greece is ranked in the areas of the planet that are considered to favor solar radiation. Greece notes sunshine duration of more than 2.700 hours per year (Š́uri, Huld, Dunlop \& Ossenbrink, 2007).

The initial investment cost of installing a photovoltaic park reaches approximately 1350 $€ / \mathrm{MWh}$, while the variable operation and maintenance cost comes near $15.1 € / \mathrm{MWh}$ (Tzouvelekis, 2014; Taliotis et al., 2017). Those values set the utility-scale solar power plant the cheapest electricity generation technology for the wider Mediterranean region. However, for Greece, following the relative social and economic parameters, the purchase and installation price of a photovoltaic park might be slightly more expensive (Giatrakos, Tsoutsos, Mouchtaropoulos, Naxakis \& Stavrakakis, 2009; Georganteas, 2011; Tzouvelekis, 2014).

The photovoltaic systems produce unstable energy, automatically generating needs for setting, controlling, storing and eventually use the power. Inverters convert the direct current into alternating current which is suitable for powering the mains and provide the possibility of incorporating protective devices that automatically disconnect the system if there are 
anomalies on the grid or the generator. At the same time, it is necessary to install electric accumulators to store excess production and use it when the production fails to meet the demand. The amount of electricity that needs to be stored in batteries, determining to some extent their size, is influenced by factors such as local conditions, energy requirements, consumption peaks and the reliability degree of the power system, but above all the maximum sunshine day number (Koronaios, 2012). The excess energy (the one over the hourly average demand), if any, charges the batteries till the point they are fully charged.

\subsection{Geothermal Power}

Geothermal energy is a part of the earth's heat that is stored in the form of hot water or steam in favorable geological conditions. Is limited to the first 3 kilometers from the earth's surface and can relatively easily be exploited. It is relatively mild, alternative and may cover a significant part of the energy needs (Gando et al., 2011). The greenhouse gas emissions generated from geothermal electric stations are on average $50 \mathrm{gs} \mathrm{CO} 2 / \mathrm{kW}-\mathrm{h}$, or approximately $5 \%$ less than the conventional coal based energy production stations (Moomaw et al., 2011). Impact of geothermal source mainly concerns a) air pollution which occurs primarily from geothermal systems of high enthalpy, b) the water and thermal pollution from the discharge of geothermal water containing dissolved salts from which heat is extracted, c) the risk for (minor) seismic activity and subsidence, $d$ ) the leaks that occur mainly in the early stages of exploitation and e) the noise. It is known that the geothermal energy has many advantages compared to the solar energy systems (Li, Bian, Liu, Zhang \& Yang, 2015). These advantages include: a) not affected by weather conditions, b) it is considered the energy of base load c) is energy of constant flow with low capacity factor (over $90 \%$ in many cases) d) requires less land surface and has less ecological impact. The total installed capacity of geothermal systems, however, is much less than the solar ones (Pohekar \& Ramachandran, 2004).

Internationally the average annual rate of the market growth for the last five years is estimated at $5 \%$, while by 2020 the total power capacity is expected to reach up to approximately 20GW (Romitti, 2015).

Geothermal generated electricity does not depend upon fuel, thus the whole investment is not affected by fuel cost fluctuations. Nevertheless, capital amounts are considered high with drilling standing for almost the half of the total investment and deep resources exploration involving serious risks. An ordinary well doublet in the USA supporting approximately $5 \mathrm{MW}$ can cost to drill nearly 10 million $€$, with a $15 \%$ failure rate. The total construction of the station can cost about 4 million $€$ per MW capacity, with the levelised energy costs being at about $7 € / \mathrm{kW}$-h. Note that enhanced geothermal installations may cost well above the previously mentioned estimations (Sanyal, Morrow, Butler \& Robertson-Tait, 2007).

\subsection{Biofuels Power}

Biomass is biological material originating from living or recently living organisms. As an energy source, biomass can be used either directly through combustion to produce heat, or indirectly after the transformation into a number of biofuel types believed to be inherently environmentally friendly (Acheampong, Gyasi, Darko, Apau \& Addai-Arhin, 2016). Biomass 
is produced every day by human economic activity in the world and it is estimated to reach 105 petagrams carbon annually, equally apportioned in land and sea (Field, 1998). The conversion of biomass into biofuel may be accomplished using different methods, which are sorted into thermal, chemical and biochemical (Demirbas, 2009).

The biological sources used to produce biomass, hence biofuels, vary depending on the region. In the USA for example the forest by-products (i.e. wood residues) are quite popular, while in the UK the animal husbandry residues (i.e. poultry litter) are quite commonly used, when at the same time agricultural waste are widespread used in Southeast Asia (i.e. sugar cane residues, rice husks) (Urban \& Mitchell, 2011).

The biofuel production issue has already been addressed by academic communities and scientific journals regarding the numerous technical, economic, social and environmental issues that arise during their production and use. Some of those issues regard the direct influence on the oil price reduction and the food market prices, the controversy between "food" and "fuel", the potentiality regarding poverty reduction, the energy (/electricity) ratio, requirements, balance, efficiency and sustainability, the $\mathrm{CO}_{2}$ emissions, the water resourced impacts, etc. (Cotton et al., 2015).

The International Resource Panel (Bringezu et al., 2009) in a publication regarding biofuels, abstracted the extended and correlative determinants needed to be considered in a decision making procedure regarding the comparative advantages of one biofuel over another, noting that different types of biofuels have different impacts on ecosystem, climate and offer different energy supply safety, thus it recommended that social and environmental impacts need to assessed during the entire life cycle.

\subsection{Hydropower}

Hydroelectric power is one of the oldest methods of producing power (Murthy \& Hegde, 2015). Hydroelectricity is the term commonly used for large scale hydroelectric dams. Such power installations typically produce up to $100 \mathrm{~kW}$ power. Hydropower is currently produced in 150 countries, and represents about $16 \%$ of the total electricity production (Apergis, Chang, Gupta \& Ziramba, 2016), while it is estimated that $2 / 3$ of the economically feasible potential remain to be developed (Santos, Vieira, Tiago Filho, Barros \& Souza, 2016).

Hydropower is mainly connected with the energy deriving from falling water. The operation of such hydroelectric stations is based on the water moving due to a height difference between the entry and exit point. When the water falls it moves a turbine, which turns the generator on. For that reason, a water reservoir is usually constructed. The amount of energy produced by the generator is usually determined by the volume of the water falling/running. The large scale hydroelectric projects (over 30MW) can have significant negative social and environmental impacts (Habich, 2016). For example, the construction of reservoirs (dams) restricts the natural fishery movement affecting the entire surrounding ecosystem, radically changing its morphology (Smith, Meiners, Hastings, Thomas \& Colombo, 2017).

Advantages of the hydropower falling water stations besides being a clean and renewable energy source is that they can be put into operation at will, providing an energy supply safety, 
while through the water reservoirs certain needs can also be satisfied, such as water supply. On the other hand, the huge construction and operation costs, the long construction time and the intense environmental degradation of the surrounding area are certainly considered notable disadvantages of that kind of projects (Kelly-Richards, Silber-Coats, Crootof, Tecklin \& Bauer, 2017).

However, other types of hydropower are emerging the last five years; tidal power and wave power. Those technologies, although not currently a widely employed alternative, have proofs of being a giant power reservoir whose potential could reach $120 \mathrm{~K} \mathrm{TWh}$ annual output (Clément et al., 2002), and hence should be widely considered.

\section{Methodology}

This research attempts to address the energy needs of Zakynthos Island using exclusively one renewable energy system. For the aim of the current research, we examine through multi-criteria decision-analysis the following applicable renewable energy source alternatives; Biofuels Production Station, Geothermal Power Station, Hydroelectric Power Station, Solar Power Station and Wind Power Station.

First, due to the relation between the three pillars of sustainability, namely, the environment, the society and the economy, we develop sub-criteria under those three pillars in the context of the scope of the current research (Figure 2). The multi-criteria analysis follows two steps. At first, we proceed in weighting the criteria and sub-criteria using Saaty's pairwise comparison method (Saaty, 1987), within the framework of the multi-criteria decision making method of Analytical Hierarchy Process, which provides the ability to control the consistency in the determination of criterion weight (Cristobal, 2014). Then, we develop a typical linear scale (see Table 5) in order to evaluate all developed criteria and sub-criteria. For the overall score, we multiplied each criterion's and sub-criterion's weight resulting from the pairwise comparison with the evaluation score deriving from the aforementioned scale use.

For the purposes of this study, the criteria and sub-criteria weighting using Saaty's pairwise comparison method was subject to the author's point of view. However, and in order to address this multidimensional and multidisciplinary issue, for the evaluation using the developed linear scale, standardized interviews were considered the most suitable approach, as one reflecting personal experiences, perception and beliefs of the evaluators which can be regarded as experts by experience and expertise. 


\section{Ml Macrothink}

Thereupon, a group of experts ${ }^{1}$ in the relative field and a group of decision makers ${ }^{2}$ were interviewed $(\mathrm{N}=10+1)$. The interviewees were asked to evaluate the twenty-seven criteria for each of the five given alternatives. The first group was given full evaluation strength, whiles the second group, the decision makers was given half evaluation strength, considering that political perceptions could determine their judgment. To get the overall evaluation score, we summed up the results.

The sampling process did not aim to achieve a representative sample, but was used as a strategy in order to provide more accurate and acceptable results. This we achieved through the purposive sampling technique (Guarte and Barrios, 2006) which concerns selecting individuals taking an active part in renewable energy research and implementation procedures and who are likely to contain the most information on the under study issue.

Sub-criteria were developed aiming the maximum contribution of each renewable energy source in the energy mix, ensuring compliance with the environmental and ecological constraints, as expressed from the Islands' characteristics, compatibility with the current economic, legislative and political conditions and compliance with the technical and technological circumstances of the area concerned and the technical specifications of the proposed alternatives.

In order to address this multi-criteria decision analysis case, we use the online tool TransparentChoise (www.transparentchoice.com). A decision making set of tools based on Analytical Hierarchy Process (AHP) aiming to help decision makers to conclude to a rational and transparent choice.

\footnotetext{
${ }^{1}$ While the interviewed experts provided invaluable perspective and advice to this study, they may have different views on one or more matters addressed in this research paper. They were not asked to individually or collectively endorse this research's method, findings and recommendations. 1. Associate Professor, Aarhus University, School of Business and Social Sciences, Department of Business Development and Technology, 2. Lecturer, University of Leeds, School of Civil Engineering, 3. Lecturer, Open University of Cyprus, Faculty of Pure and Applied Sciences, Environmental Conservation and Management, 4. Research Consultant, Aristotle University of Thessaloniki, 5. Scientific Assistant, FernUniversitat in Hagen, 6. Assistant Director, Centre for Renewable Energy Sources and Saving, 7. Environmental Applied Economics Expert, Centre for Renewable Energy Sources and Saving, RES Division, Geothermal Energy Department.

${ }^{2}$ While the interviewed decision makers provided invaluable perspective and advice to this study, they may have different views on one or more matters addressed in this research paper. They were not asked to individually or collectively endorse this research's method, findings and recommendations. 1. Member of the Hellenic Parliament and Minister of the Interior and Administrative Reconstruction of the Hellenic Republic, former Minister of Environment and Energy of the Hellenic Republic, 2. Member of the Hellenic Parliament for Zakynthos and Minister of Justice, Transparency and Human Rights, former Deputy Minister for Sports, 3. former Member of the Hellenic Parliament for Zakynthos, former Prefect of Zakynthos
} 


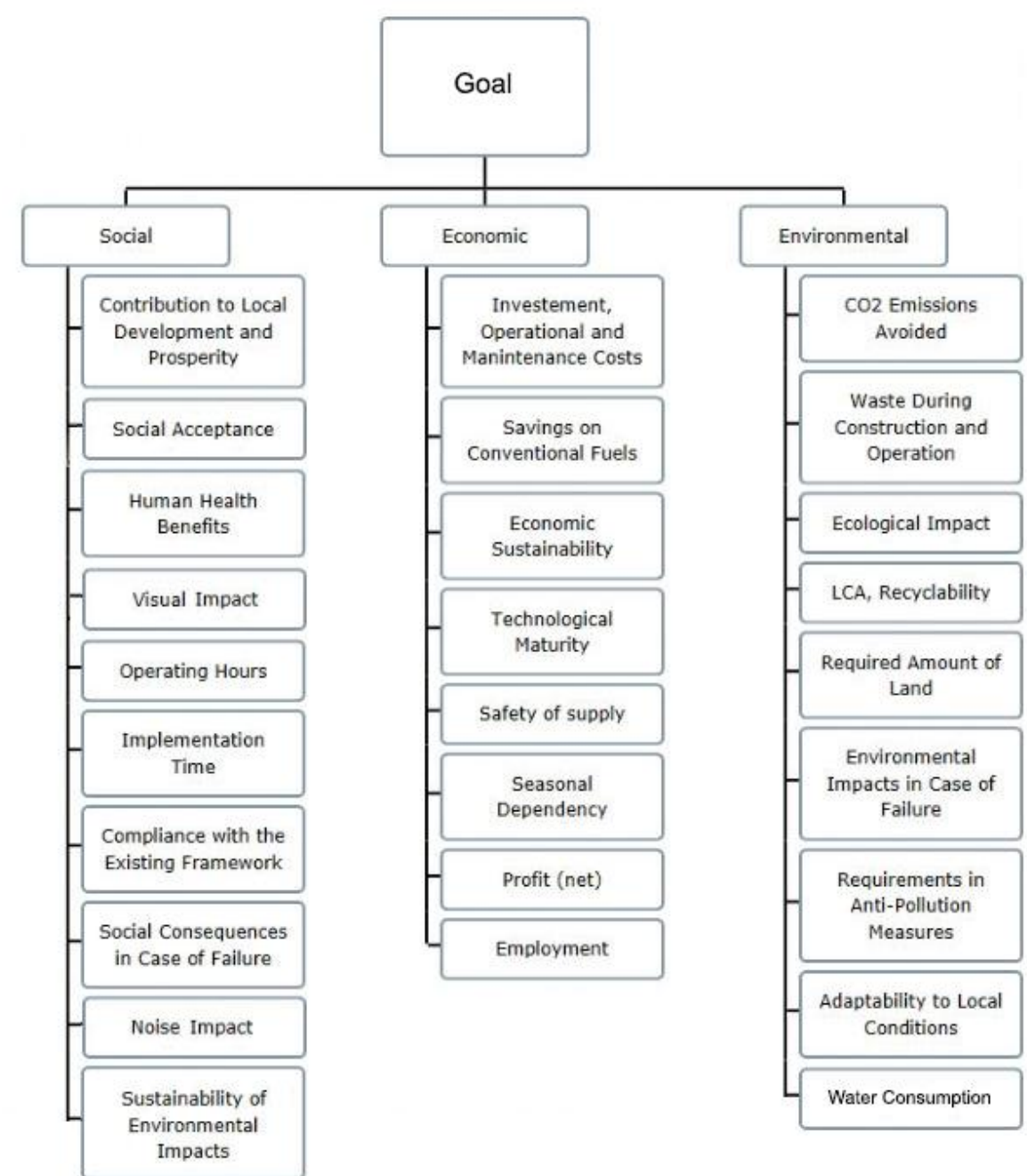

Figure 2. Goal flow chart including criteria and sub-criteria

\section{Results}

The number of alternatives or possible solutions requires the application of a decision support method (Niemeijer, 2002). Economic variables, energy efficiency or environmental impact are currently affected by uncertainty (Howlett \& Cuenca, 2016). Hence the importance of multi-criteria analysis arises, to address this high level of complexity and uncertainty (Keseru, Bulckaen \& Macharis, 2016), given that, multi-criteria analysis can handle numerous indicators, data, variables and alternatives. Thus a valuable assistance in decision making is offered, for each case study, following the evaluation and even the under-evaluation of each criterion and sub-criterion separately (Triantaphyllou, 2000). Of course, this method does not replace the decision makers (actors), but rather supports them in all procedure stages, providing useful information (Figueira, Greco \& Ehrogott, 2005).

The identification and selection of criteria and sub-criteria, aims to include all possible parameters set for studying the potential alternatives, in an attempt to build a representative 
structure of specific characteristics and to avoid duplicates and overlaps. Thus, twenty-seven total sub-criteria have been developed, which are respectively classified into three criteria groups, in line with the scope of the current research, 9 addressing the environmental pillar, 8 the economic pillar and 10 the society as accordingly presented in Tables 2,3 and 4.

Table 2. Sub-criteria of the environmental pillar

\begin{tabular}{|c|c|}
\hline $\begin{array}{l}\text { CO2 emissions } \\
\text { avoided }\end{array}$ & $\begin{array}{l}\text { RES exploitation is an essential mean of mitigation of } \mathrm{CO} 2 \text { emissions. This constitutes } \\
\text { several criteria for the reduction of } \mathrm{CO} 2 \text { emissions because they have a direct impact } \\
\text { on human life and an indirect impact on society ( } \mathrm{tCO} 2 / \mathrm{y}) \text {. }\end{array}$ \\
\hline $\begin{array}{l}\text { Waste production } \\
\text { during construction } \\
\text { and operation }\end{array}$ & $\begin{array}{l}\text { Construction and operational waste are of the heaviest and most voluminous waste } \\
\text { streams generated. Consist of numerous materials, including concrete, bricks, gypsum, } \\
\text { wood, glass, metals, plastic, solvents, asbestos and excavated soil, many of which can } \\
\text { be recycled (w/y). }\end{array}$ \\
\hline Ecological impact & $\begin{array}{l}\text { Effects on the living organisms and their non-living (abiotic) environment due to } \\
\text { human activity or natural phenomenon. }\end{array}$ \\
\hline LCA, Recyclability & $\begin{array}{l}\text { Includes upstream (i.e., manufacture, construction, mining), O\&M, and downstream } \\
\text { (i.e., decommission/disposal) emissions of } \mathrm{CO} 2, \mathrm{CH} 4, \mathrm{~N} 2 \mathrm{O} \text {. }\end{array}$ \\
\hline $\begin{array}{l}\text { Required amount of } \\
\quad \text { land }\end{array}$ & $\begin{array}{l}\text { On-site direct operational: land occupied by power plant during operation (include life } \\
\text { cycle land use as upper bound). Also, renewable energy production systems require a } \\
\text { larger use of land compared to conventional sources. This fact is capable of prompting } \\
\text { negative public reactions. }\end{array}$ \\
\hline $\begin{array}{l}\text { Environmental } \\
\text { impacts in case of } \\
\quad \text { failure }\end{array}$ & $\begin{array}{l}\text { Continuous changes in technology, environmental regulation, and public safety } \\
\text { concerns make the analysis of the safety of energy systems more and more demanding. } \\
\text { Reliability of energy systems is the capacity of a device or system to perform as } \\
\text { designed and its resistance to failure. }\end{array}$ \\
\hline $\begin{array}{l}\text { Requirements in } \\
\text { Anti-Pollution } \\
\text { Measures }\end{array}$ & $\begin{array}{l}\text { Pollution is an example of a negative externality - a cost imposed on a third party. } \\
\text { Therefore anti-pollution measures are implemented which can include infrastructure } \\
\text { regulations, taxes, pollution permits, etc. }\end{array}$ \\
\hline $\begin{array}{l}\text { Adaptability to local } \\
\text { conditions }\end{array}$ & $\begin{array}{l}\text { The need for adaptability in energy emergencies has implications for energy policy } \\
\text { during nonemergency times. For example, the ability of an energy system to adapt to } \\
\text { acute shortage depends in part on its ability to curtail demand quickly, which, in turn, } \\
\text { depends on the pre-existing pattern of local energy use. }\end{array}$ \\
\hline Water Consumption & $\begin{array}{l}\text { The water footprint of the energy mix is significantly important and can have } \\
\text { implications for energy policy development. }\end{array}$ \\
\hline
\end{tabular}

Table 3. Sub-criteria of the economic pillar

\begin{tabular}{|c|l|}
\hline $\begin{array}{c}\text { Investment, operational } \\
\text { and maintenance costs }\end{array}$ & $\begin{array}{l}\text { Ratio of sum of the amortized overnight capital costs \& O\&M costs to annual } \\
\text { electricity generation; assumes constant financing cost and project lifetime. }\end{array}$ \\
\hline $\begin{array}{c}\text { Savings in conventional } \\
\text { fuels }\end{array}$ & $\begin{array}{l}\text { This criterion refers to the total quantity of conventional fuels which is replaced by } \\
\text { power generation from renewable energy systems. }\end{array}$ \\
\hline Economic sustainability & $\begin{array}{l}\text { Renewable energy is not just about saving the environment any more. It is now also } \\
\text { about stimulating the economy, generating new sources of growth, increasing } \\
\text { income and improving trade balances. }\end{array}$ \\
\hline
\end{tabular}




\begin{tabular}{|c|l|}
\hline Technological maturity & $\begin{array}{l}\text { This criterion refers to the reliability degree of the adopted technology and its } \\
\text { spread at national and European level. }\end{array}$ \\
\hline Safety of supply & $\begin{array}{l}\text { This criterion reflects whether the energy supply faces any interruptions. The } \\
\text { presence of such interruptions affects the stability of the electricity network. }\end{array}$ \\
\hline Seasonal dependency & $\begin{array}{l}\text { The renewable power generation aggregated across Europe exhibits strong seasonal } \\
\text { behaviors that need to be calculated of counterbalanced. }\end{array}$ \\
\hline Profit (net) & Net profit as a measure of the venture profitability after accounting all costs. \\
\hline Employment & $\begin{array}{l}\text { Direct, indirect and induced full-time equivalent (FTE) employment during } \\
\text { construction and operation stages. }\end{array}$ \\
\hline
\end{tabular}

Table 4. Sub-criteria of the social pillar

\begin{tabular}{|c|c|}
\hline $\begin{array}{l}\text { Contribution to local } \\
\text { development and } \\
\text { prosperity }\end{array}$ & $\begin{array}{l}\text { This criterion estimates the total social and economic impact that may become } \\
\text { perceptible in the regions that house the sustainable energy systems. Likely results are: } \\
\text { new chains of enterprises for energy supply, emerging enterprises in the energy sector, } \\
\text { new industrial regions, etc. }\end{array}$ \\
\hline Social acceptance & $\begin{array}{l}\text { The opinions related to the energy systems of the local population regarding the } \\
\text { hypothesized realization of the projects under review. It is extremely important since } \\
\text { the opinions of the population and pressure groups may heavily influence the amount } \\
\text { of time needed to complete an energy project. }\end{array}$ \\
\hline $\begin{array}{l}\text { Human health } \\
\text { benefits }\end{array}$ & $\begin{array}{l}\text { Renewable electricity projects and energy efficiency measures could have health } \\
\text { benefits worth millions of dollars a year. However, the value of such projects varies } \\
\text { greatly depending on the type of project. }\end{array}$ \\
\hline Visual impact & $\begin{array}{l}\text { The installation and operation of renewable energy systems is a relevant transformation } \\
\text { of the circumferential territory for various reasons (land footprint, aesthetic degradation } \\
\text { of the landscape, glare, etc.) thus the existed concerns of local communities and } \\
\text { governments about the environmental, territorial and landscape impacts of those } \\
\text { systems. }\end{array}$ \\
\hline Operating hours & $\begin{array}{l}\text { To meet its electricity requirements, a renewable energy unit can operate endlessly or } \\
\text { not. The operating time is determined for a society since many social and economic } \\
\text { factors are at stake. }\end{array}$ \\
\hline Implementation time & $\begin{array}{l}\text { The time required to complete the installation of a renewable energy unit plays an } \\
\text { important role in a local community, and when combined with economic and } \\
\text { environmental factors can be deterring factor for the whole project. }\end{array}$ \\
\hline $\begin{array}{l}\text { Compliance with the } \\
\text { existing framework }\end{array}$ & $\begin{array}{l}\text { Those multidisciplinary solutions, being new to humanity, are under hundreds of } \\
\text { regulations and frameworks around the world and even more at local sites. Compliance } \\
\text { issues should be taken seriously, investigate each one, and revisit all operational } \\
\text { controls, costs, impacts, etc. }\end{array}$ \\
\hline $\begin{array}{l}\text { Social consequences } \\
\text { in case of failure }\end{array}$ & $\begin{array}{l}\text { Deaths from accidents involved in power plant manufacture, construction, operation; } \\
\text { fuel extraction, processing, storage, transportation; waste treatment, disposal, etc. }\end{array}$ \\
\hline Noise impact & $\begin{array}{l}\text { The construction and operation of renewables developments will lead, among other } \\
\text { things (land use disrupt, visual disturbance, etc.), to acoustic annoyance. The extend of } \\
\text { which depends on the technology used. As a result, whether a particular project would } \\
\text { result in undue harm to the surrounding communities, cautions that meaningful public }\end{array}$ \\
\hline
\end{tabular}




\begin{tabular}{|c|l|}
\hline \multicolumn{1}{c|}{} & involvement is crucial for acceptance. \\
\hline \multirow{3}{*}{$\begin{array}{c}\text { Sustainability of } \\
\text { environmental } \\
\text { impacts }\end{array}$} & $\begin{array}{l}\text { All energy sources have some impact on our environment. Fossil fuels do substantially } \\
\text { more harm than renewable energy sources, however, is still important, to understand } \\
\text { the environmental impacts associated with producing power from renewable sources. } \\
\text { The exact type and intensity of environmental impacts vary depending on the specific } \\
\text { technology used. }\end{array}$ \\
\hline
\end{tabular}

The evaluation in the context of the given alternatives for the parameters of the environmental, economic and social criteria, resulting from the pairwise comparison approach shows (Fig. 3) that the environment owns a significant important weight (49.3\%), followed by the social criterion (31.1\%) and the economic pillar (19.6\%). In addition, we present in detail every sub-criterion weight in Figures 4, 5 and 6. Thus, the most contributing indicators, resulting from the pairwise comparison, are the "Sustainability of environmental impacts" deriving from the social criterion with $11.9 \%$ global weight ${ }^{3}$ significance followed by " $\mathrm{CO}_{2}$ emissions avoided" representing the environmental criterion with a $11.1 \%$ weight significance, the "Required amount of land" also from the environmental criterion with a $8.5 \%$ weight significance and the "Savings in conventional fuels" coming from the economic parameter with a $6.3 \%$ weight significance.

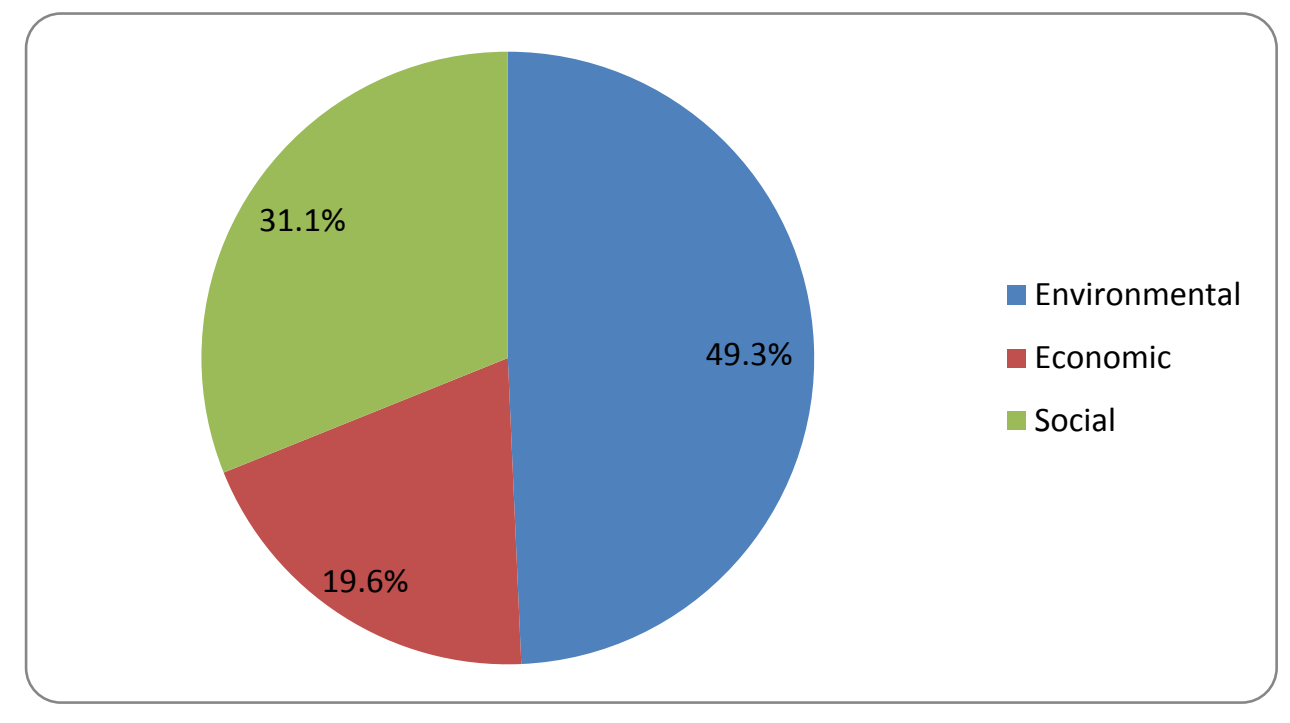

Figure 3. Pairwise comparison primary criteria evaluation

\footnotetext{
${ }^{3}$ Global Weight: the contribution that each criterion makes to the overall score, not the weight of each criterion within its own category in the hierarchy. It is calculated as the product of weight up the hierarchy. For example the criterion "Sustainability of environmental impacts" is calculated as: $38.4 \%$ (S-Cr local weight) x $31.1 \%$ (the local weight of the parent of the sub-criterion, social criterion) $=11.9 \%$.
} 


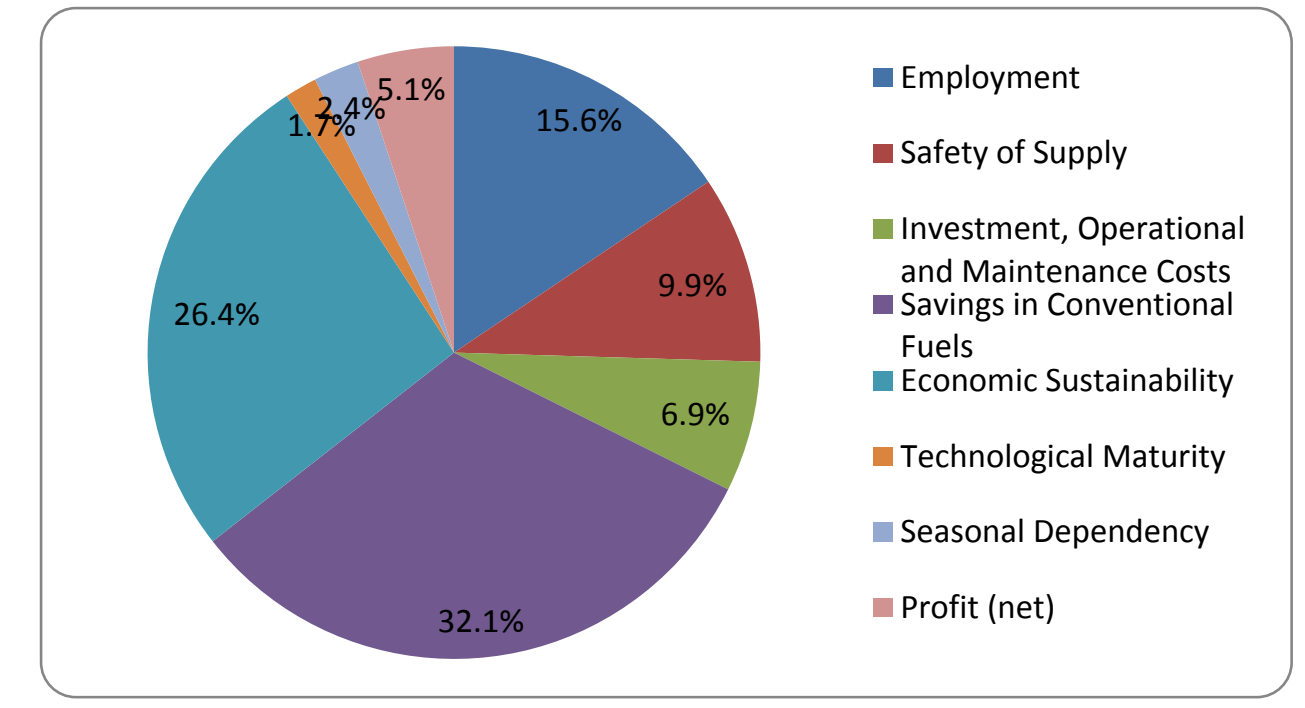

Figure 4. Sub-criteria pairwise comparison evaluation in the context of economic criterion

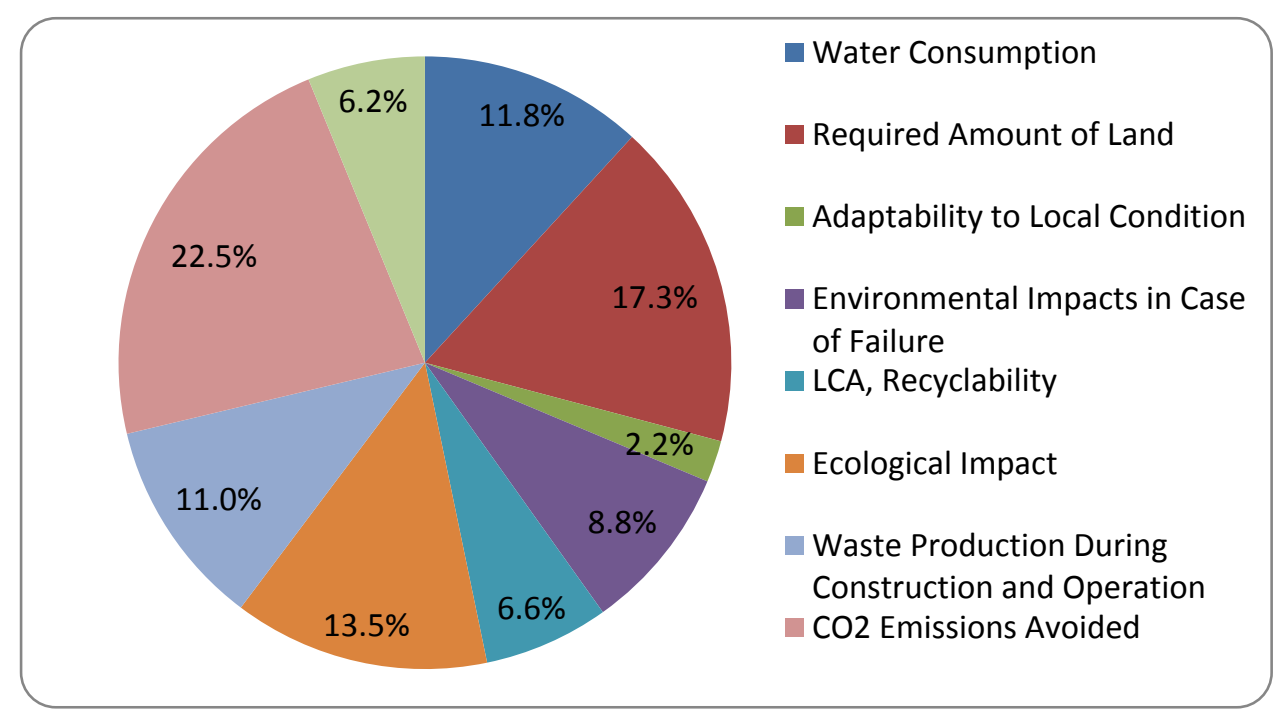

Figure 5. Sub-criteria pairwise comparison evaluation in the context of environmental criterion 


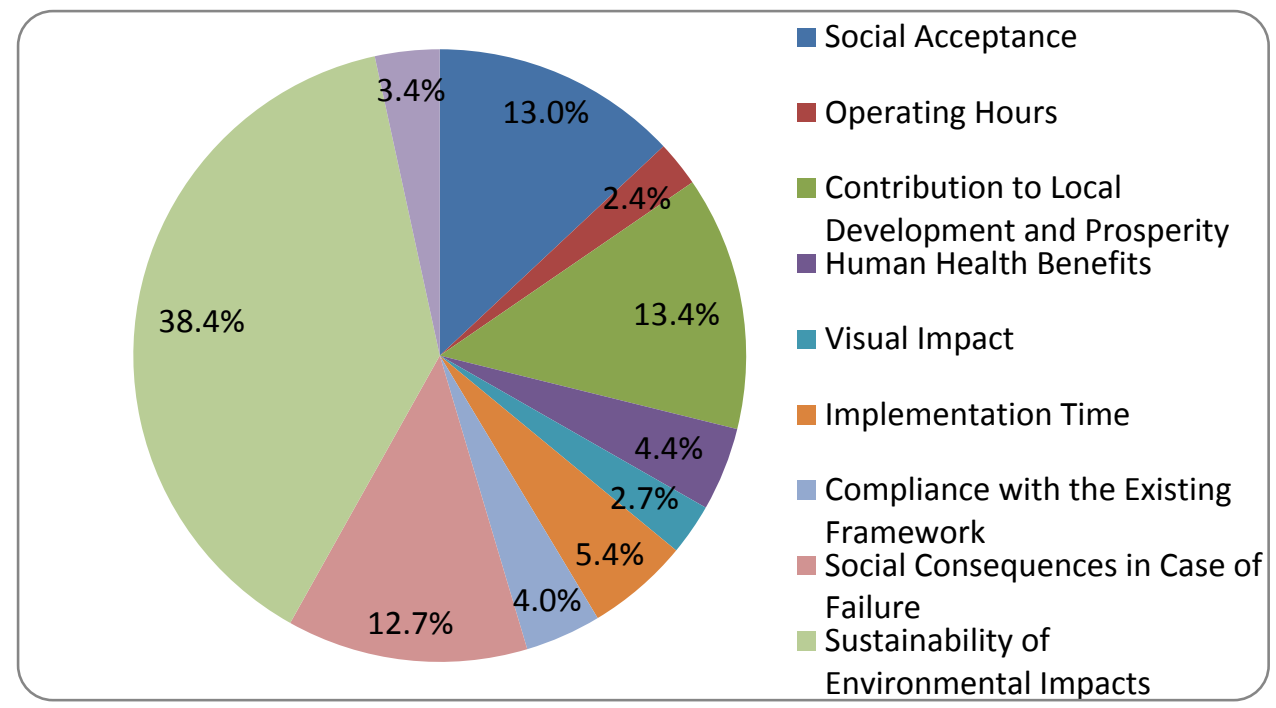

Figure 6. Sub-criteria pairwise comparison evaluation in the context of social criterion

In line with the methodology followed for the scope of the current research and in accordance with the multi-criteria decision-analysis steps, in order to compare the alternatives, it is necessary to assess and evaluate the evaluate each criterion and sub-criterion with regard to the characteristics and the degree of influence it holds in this case. For that reason, a typical linear weight evaluation scale is developed and used (Table 5).

Table 5. Criterion Weight Evaluation Scale

\begin{tabular}{|c|c|}
\hline Numerical Scale & Verbal Scale \\
\hline 1 & None - Zero Importance \\
\hline 2 & Weak Importance \\
\hline 3 & Moderate Importance \\
\hline 4 & Strong Importance \\
\hline 5 & Very Strong Importance \\
\hline 6 & Extreme Importance \\
\hline
\end{tabular}

In Tables 6, 7 and 8 we present the survey evaluation results of each sub-criterion. We also note (black arrow) the alternative that holds the highest score in every sub-criterion, in a successful attempt to point the alternative holding the most "high scores".

Table 6. Environmental sub-criteria evaluation survey results

\begin{tabular}{|c|c|c|c|c|c|}
\hline Environmental Criterion & B & G & H & S & W \\
\hline $\mathrm{CO}_{2}$ Emissions Avoided & 3.74 & 4.42 & 4.32 & $4.84 \mathbf{4}$ & 4.63 \\
\hline Waste Production During Construction \& Operation & 3.37 & 3.47 & 3.32 & $4.16 \mathbf{4}$ & 3.11 \\
\hline Ecological Impact & $3.53 \mathbf{4}$ & 3.42 & 2.95 & 3.47 & 3.47 \\
\hline LCA, Recyclability & $4.11 \mathbf{4}$ & 3.26 & 3.16 & 3.63 & 3.53 \\
\hline Required Amount of Land & 3.42 & 3.58 & 3.58 & $3.68 \mathbf{4}$ & 3.68 \\
\hline Environmental Impacts in Case of Failure & 4 & 3.37 & 4.11 & $4.84 \mathbf{4}$ & 3.53 \\
\hline Requirements in Anti-Pollution Measures & 3.47 & 3.11 & 3.79 & $4.47 \mathbf{4}$ & 3.58 \\
\hline
\end{tabular}




\begin{tabular}{|c|c|c|c|c|c|}
\hline Adaptability to Local Condition & 3.954 & 3.79 & 3.84 & 3.47 & 3.53 \\
\hline Water Consumption & 3.63 & 3.89 & 4.794 & 4.95 & 3.84 \\
\hline B: Biofuels Production Station | G: Geothermal Power Station | H: Hydroelectric Power Station \\
S: Solar Power Station | W: Wind Power Station \\
\hline
\end{tabular}

Table 7. Economic sub-criteria evaluation survey results

\begin{tabular}{|c|c|c|c|c|c|}
\hline Economic Criterion & B & G & H & S & W \\
\hline Investment, Operational \& Maintenance Costs & 3.26 & 3.16 & 3.47 & 4.11 4 & 3.79 \\
\hline Savings in Conventional Fuels & 3.84 & 4.53 & 4.42 & 4.53 4 & 4.53 \\
\hline Economic Sustainability & 3.79 & 3.79 & 3.53 & 4.054 & 4 \\
\hline Technological Maturity & 4.11 & 4.37 & 4.794 & 4.37 & 4.68 \\
\hline Safety of Supply & 3.53 & 4.42 & $4.47 \mathbf{4}$ & 3.89 & 3.63 \\
\hline Seasonal Dependency & 3.47 & 2.95 & 3.26 & 4.16 & 4.264 \\
\hline Profit (net) & 3.42 & 3.53 & 3.84 & 3.79 & 3.894 \\
\hline Employment & $4 \mathbf{4}$ & 3.74 & 3.26 & 3.16 & 3.05 \\
\hline
\end{tabular}

B: Biofuels Production Station | G: Geothermal Power Station | H: Hydroelectric Power Station S: Solar Power Station | W: Wind Power Station

Table 8. Social sub-criteria evaluation survey results

\begin{tabular}{|c|c|c|c|c|c|}
\hline Social Criterion & B & G & H & S & W \\
\hline Contribution to Local Development \& Prosperity & 3.79 & 3.63 & 3.84 & 3.84 & 4.05 4 \\
\hline Social Acceptance & 3.74 & 3.21 & 3.58 & $4 \mathbf{4}$ & 3.68 \\
\hline Human Health Benefits & 3.95 & 4.05 & 3.74 & 4.21 4 & 3.89 \\
\hline Visual Impact & $4 \mathbf{4}$ & 3.32 & 3.95 & 3.68 & 3.89 \\
\hline Operating Hours & 3.32 & 3.63 & 3.63 & 4.054 & 3.63 \\
\hline Implementation Time & 3.63 & 3.37 & 3.63 & 3.84 4 & 3.58 \\
\hline Compliance with the Existing Framework & 4.42 & 4.42 & 4.16 & 4.894 & 4.63 \\
\hline Social Consequences in Case of Failure & 3.95 & 3.63 & 3.74 & 4.264 & 3.74 \\
\hline Noise Impact & 3.63 & 3.58 & 3.47 & 5.264 & 3.79 \\
\hline Sustainability of Environmental Impacts & $4.26 \mathbf{4}$ & 3.79 & 3.53 & 4.11 & 4.05 \\
\hline B: Biofuels Production Station | G: Geothermal Power Station | H: Hydroelectric Power Station \\
S: Solar Power Station | W: Wind Power Station \\
\hline
\end{tabular}

The final ranking of the alternatives is given in the form of a bar chart (Figure 7), which lists the renewable energy alternatives under evaluation (axis-y) in conjunction with the overall alternative utility of each renewable energy scenario (axis-x). Total utility represents the total score that occupies each alternative with respect to criteria and sub-criteria satisfaction. The alternative with the highest total utility is considered the optimal one.

The final ranking, as previously mentioned, is the result of multiplying each sub-criterion's weight, resulting from the pairwise comparison (see Fig. 4, 5, 6), with the summary of the survey evaluation score for each sub-criterion, deriving from the developed linear scale use (see Tables 6, 7, 8). 


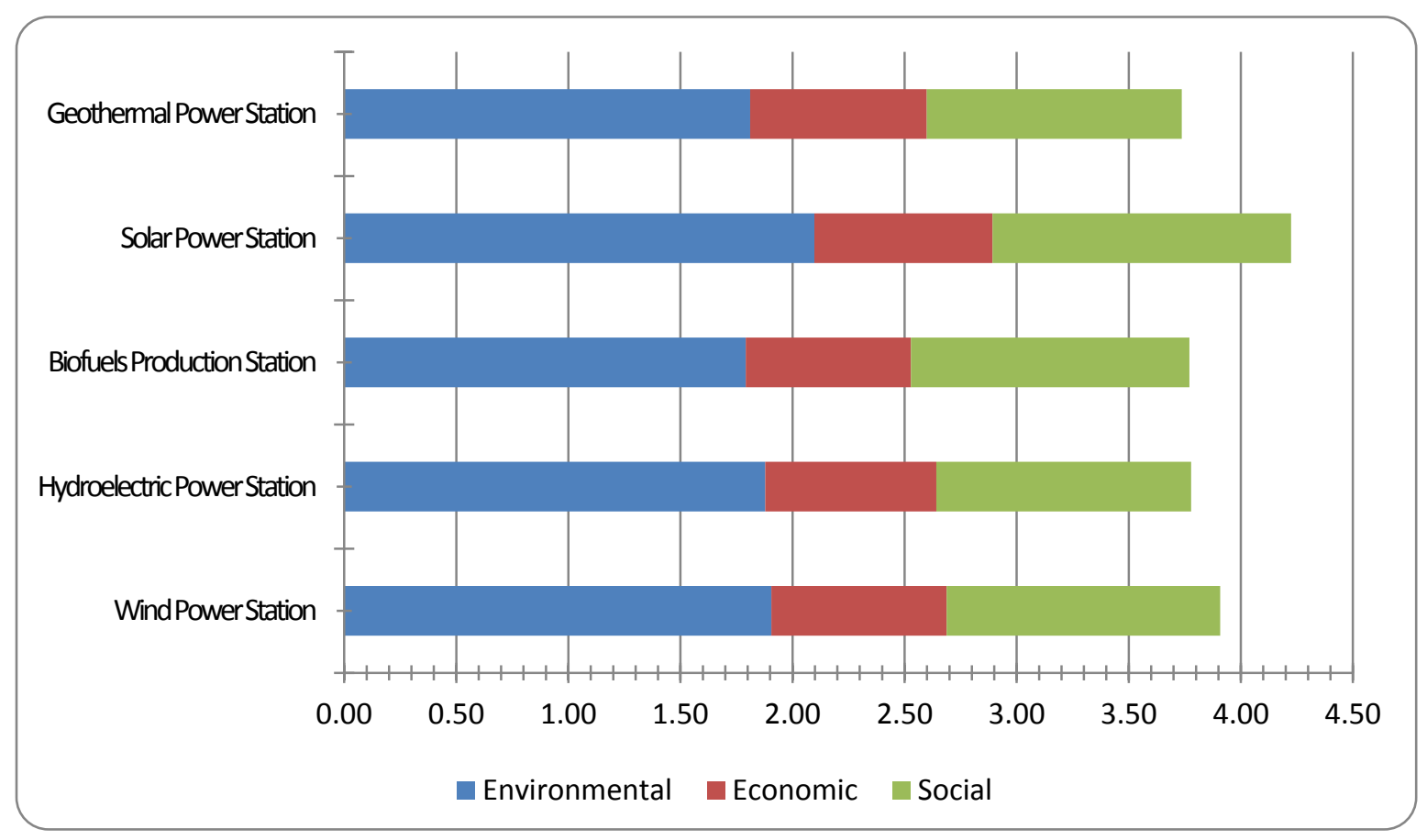

Figure 7. Alternatives Final Ranking

Developing and implementing the previously mentioned multi-criteria methodological model revealed solar power station (4.22 total score) as an RES alternative better than wind power station (3.91 total score) alternative, both better than hydroelectric power station (3.78 total score), biofuels production station (3.77 total score) and geothermal power station (3.74 total score). From the alternatives final ranking, we observe (see also Figure 8 were all criteria and sub-criteria are bottom-up displayed) certain variations among sub-criteria that utterly do not affect the final outcome, but rather highlight their significance (or insignificance). For instance, it is obvious that the "adaptability to local conditions" and the "technological maturity" are sub-criteria with poor ability to influence the final outcome, contrary to the significance of "savings in conventional fuels" sub-criterion. 


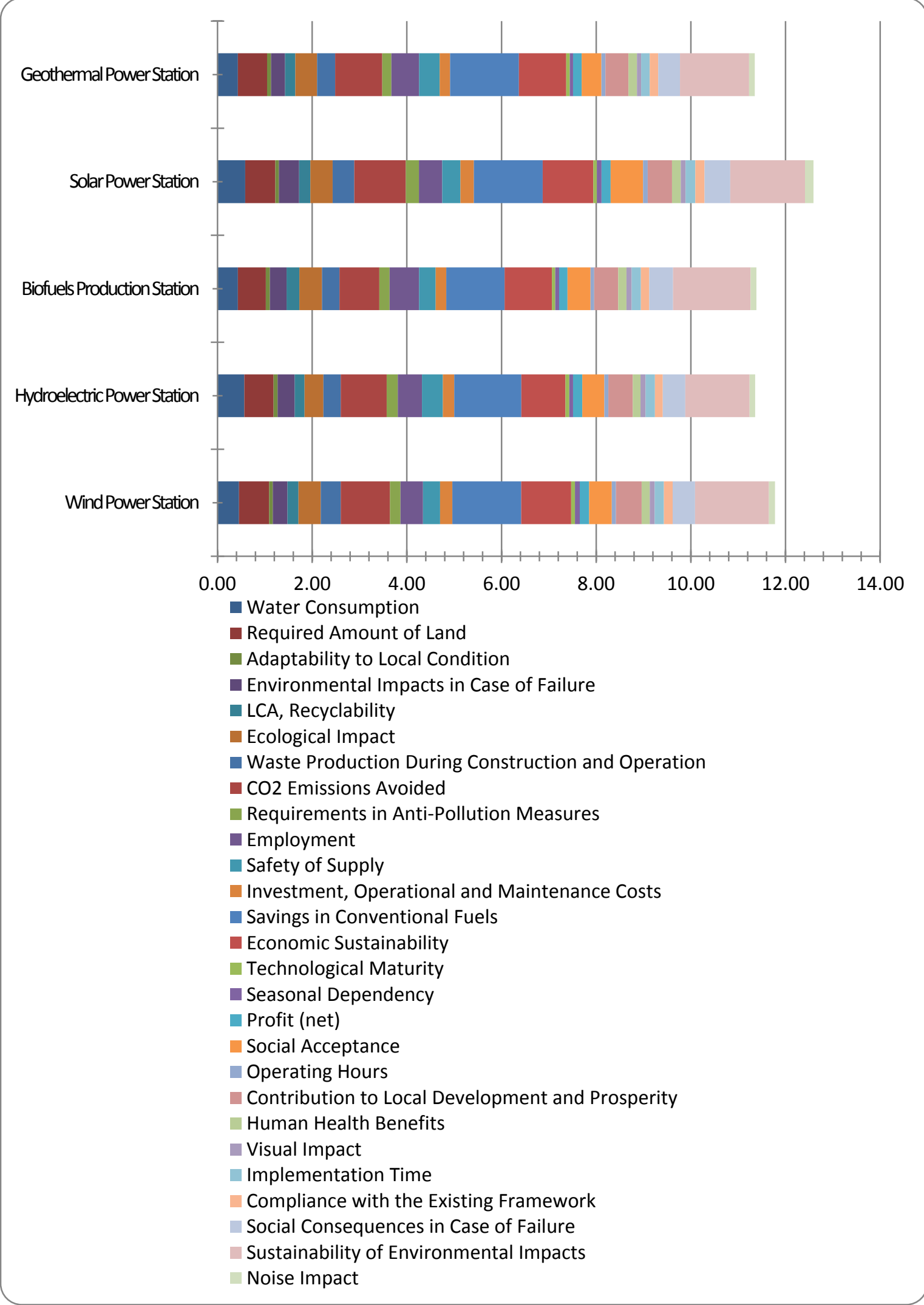

Figure 8. Alternatives final ranking (Bottom-Up Display) 


\section{Macrothink}

This result has been further strengthened from the sensitivity analysis. Sensitivity analysis gives insight into how robust the result is to changes in criteria weighting. Each horizontal line shows how the score for each alternative varies as the weighting of the criterion changes. The vertical line shows the current weighting of the criterion. Crossing lines show where the "best" alternative changes. Although the sensitivity analysis is not recommended for applying in the upper criteria of the hierarchy, since even the small change of weigh can change the order in ranking we attempt a presentation as follows in Figures 9, 10 and 11. The results provide strong evidence that alternatives ranking holds a steady behavior in response to changes in criteria weights, and therefore, we do not proceed through an extensive sensitivity analysis to each one the 27 sub-criteria. The final outcome is also in complete agreement with the adjacent chart (Fig. 12) comparison alternatives results.

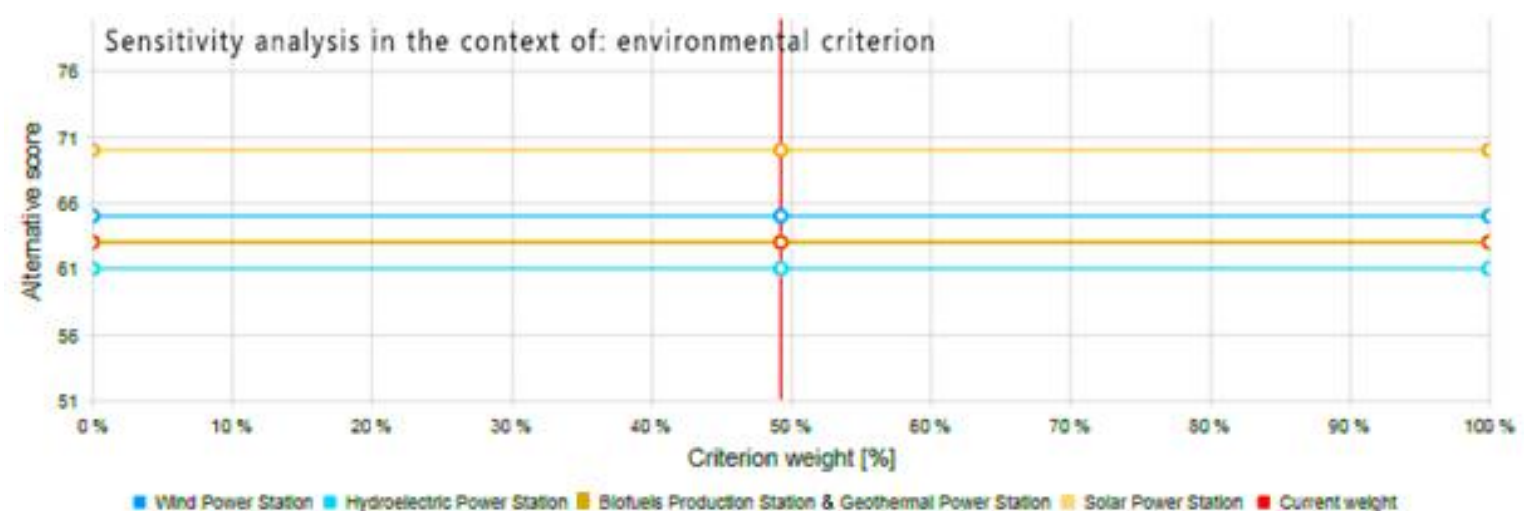

Figure 9. Sensitivity analysis in the context of: environmental criterion (normalized alternative score values)

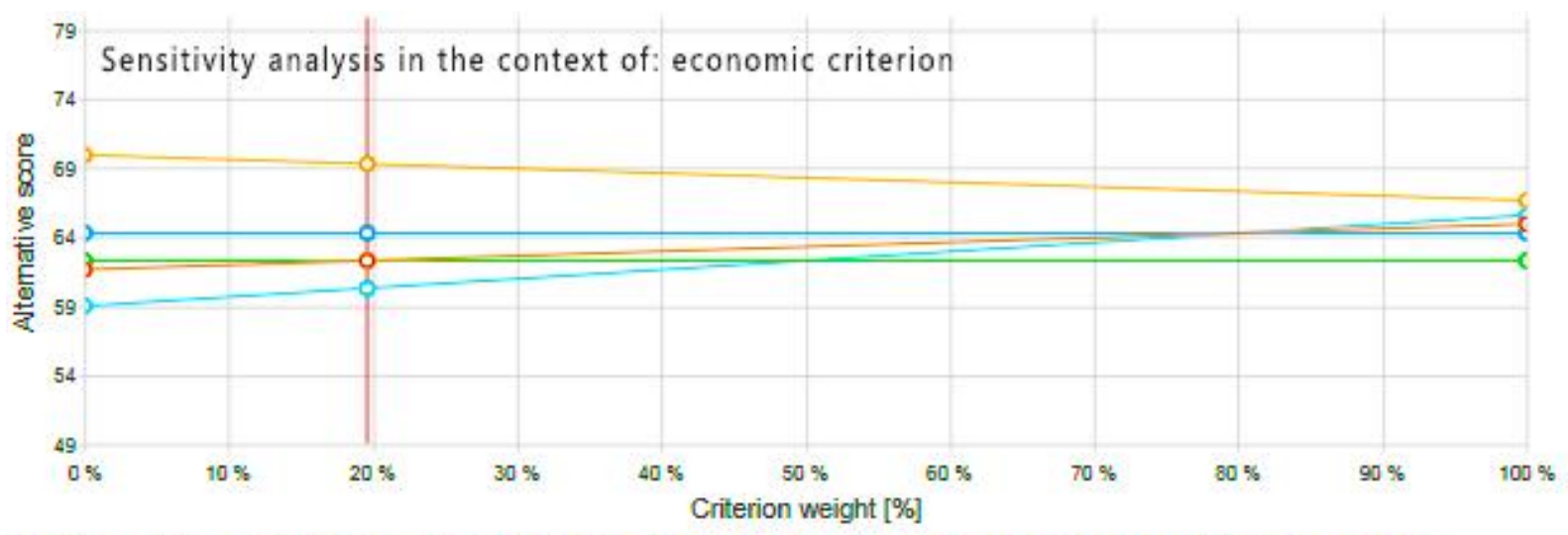

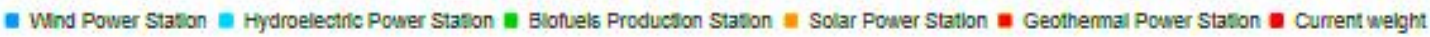

Figure 10. Sensitivity analysis in the context of: economic criterion (normalized alternative score values) 


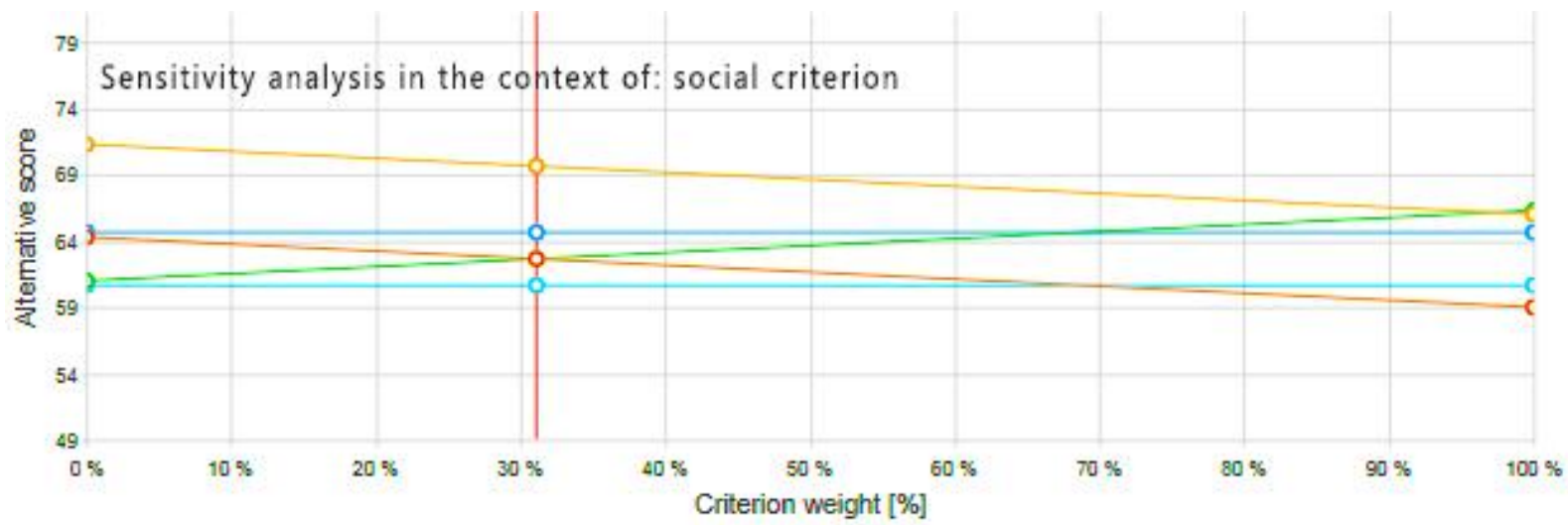

- Wind Power Station a Hydroelectric Power Station a Blofuels Production Station i| Solar Power Station a Geothermal Power Station a Current weight

Figure 11. Sensitivity analysis in the context of: social criterion (normalized alternative score values)

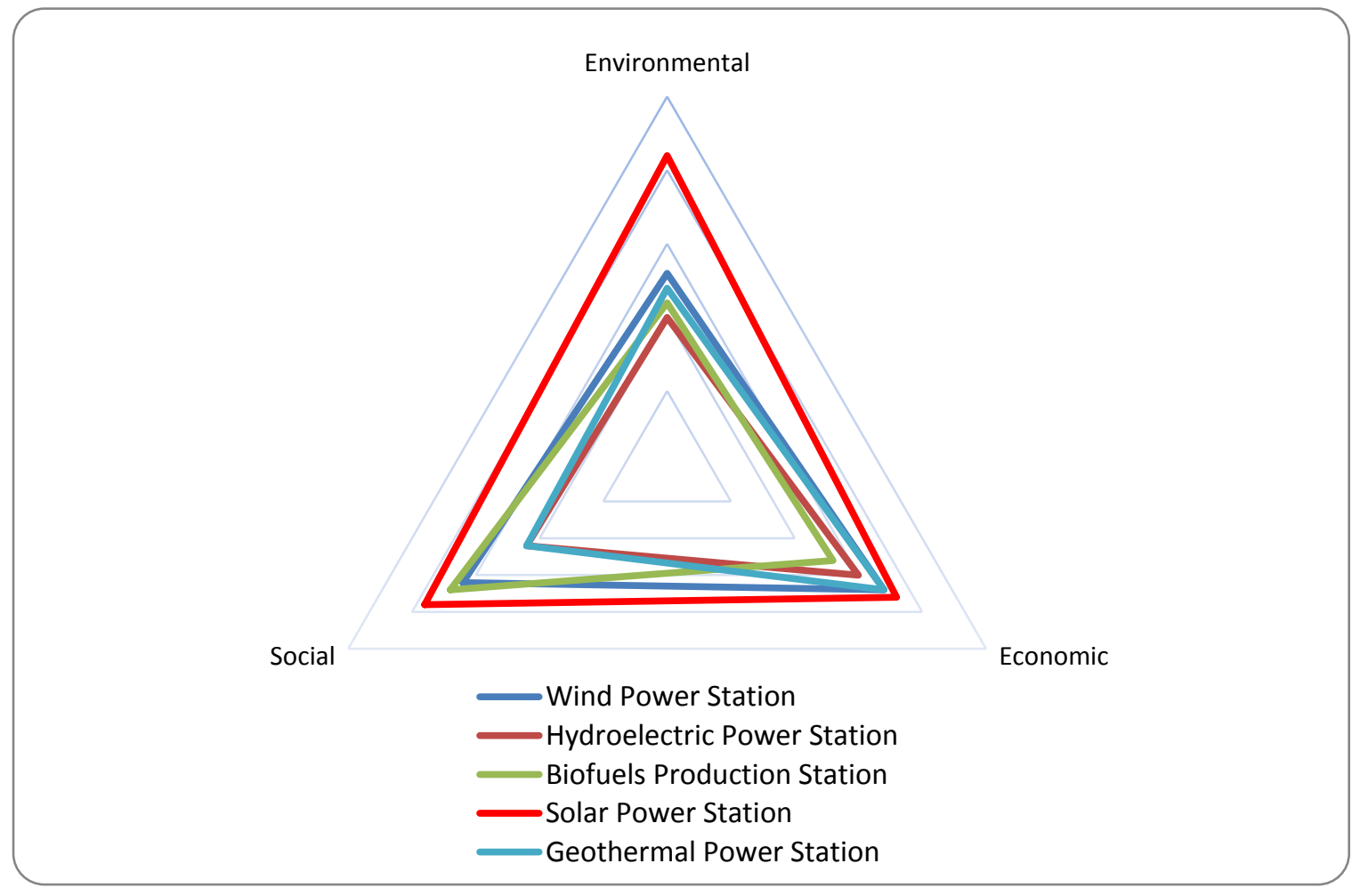

Figure 12. Alternatives comparison (normalized alternative score values)

\section{Conclusion}

The EU's energy system should ensure a sustainable, safe and competitive environment. The energy system has to transform according to the following five parameters in order to achieve its goals: a. Energy supply safety. The EU should accomplish to be less vulnerable from the energy crises coming from its energy suppliers. This will be achieved through the diversification of the energy suppliers, the use of new technologies and the use of indigenous resources. b. Support of the internal energy market through reinforced regulations regarding the cross-border energy trade and promotion and abetment of the renewable energy producers 
to further integrate into the energy market. c. Improvement of the building energy performance, particularly with regard to heating and cooling systems, through grant programs. d. Decarbonisation through advanced low emissions technologies. e. Smart technologies promotion.

To decide the most suitable and sustainable alternative for energy independence using renewable energy systems remains a considerably complicated process taking into account the delimitations of the physiognomy of the place sets, in our case Zakynthos Island. The geography, the geology, the climate, the economy, the architecture, the history, etc., are certain factors that must be taken into consideration in order to set a number of criteria.

In addition, those previously mentioned criteria must be evaluated in order to extract a final outcome/decision. As demonstrated, a multi-criteria analysis can clearly help towards this direction.

With regard to the delimitations set for the scope of the current research, results obtained, aiming at improving the quality of sustainability decisions through clear, reasonable, rational and transparent test results, indicate that the installation of a solar power station is the preferable option, as best compromised and well balanced.

Although the outcome is considered consistent with our findings obtained in our first limited attempt, given the fact that the methodology exceeds certain initial delimitations and most importantly includes all five possible applicable alternatives, the result deriving from the current research should be regarded as of primary consideration. Current study's main limitations are a. none hybrid renewable energy system was considered as an alternative, $b$. criteria and sub-criteria pairwise comparison weight evaluation was subject to the authors point of view c. the standardized questionnaire was challenging extended. However, despite the fact that this work has some limitations, we believe our work could be a springboard for setting a sustainable methodology towards addressing such multidimensional and multidisciplinary issues.

Without a doubt, in order to suggest the installation of solar power systems in the under study as the most feasible alternative to cover the island's energy needs, further research, actions, application and plans are in need. Apart from the extensive research and study regarding the alternative technologies, installation, function and combination (hybrid energy systems), considerations in order to achieve full energy independence should be taken upon:

- Maintenance and upgrade of the existing energy transmission network

- Enforcement of limitations regarding building's energy proofing

- Incentives regarding additional solutions utilizing renewable energy systems at local level (or activities, ex. agriculture)

\section{Acknowledgement}

The research was benefited from a Transparent Choice Limited student grant.

This study is a record of bonafide work done under the valued support of Professor Eleni Theodoropoulou, HUA. The author is grateful to the three anonymous reviewers for their 
valuable comments, providing valuable insights for improvements. The author would also like to acknowledge Professor Antonis Zorpas, OUC, for the introduction to the multi-criteria decision-making. Thanks are also due to the interviewed experts and decision makers and to various colleagues and acquaintances who offered helpful comments on earlier drafts.

No potential conflict of interest was reported by the author.

Any errors or omissions remain the responsibility of the author.

\section{References}

Acheampong, A., Gyasi, W., Darko, G., Apau, J., \& Addai-Arhin, S. (2016). Validated RP-HPLC method for simultaneous determination and quantification of chlorpheniramine maleate, paracetamol and caffeine in tablet formulation. Springerplus, 5(1).

http://dx.doi.org/10.1186/s40064-016-2241-2

Ageridis, G., Gaglia, A., Giannakidis, G., Daskalaki, E., Dimoudi, A., \& Dialinas, E. et al. (2011). Training Energy Inspectors. Educational material. A: Building Inspection. Lecture, Technical Chamber Of Greece, Athens. Retrieved from https://goo.gl/CBkcsC

Amatya, R., Brushett, F., Campanella, A., Kavlak, G., Macko, J., ... Tuller, H. (2015). The Future of Solar Energy: An Interdisciplinary MIT Study. Massachusetts Institute of Technology. ISBN: 978092800898 Retrieved from https://goo.gl/CbYK5Y

Andrews, C., Dewey-Mattia, L., Schechtman, J., \& Mayr, M. (2015). Alternative Energy Sources and Land Use. In G. Ingram \& Y. Hong, Climate Change Policies and Land Policies (pp. 91-121). Lincoln Institute of Land Policy.

Apergis, N., Chang, T., Gupta, R., \& Ziramba, E. (2016). Hydroelectricity consumption and economic growth nexus: Evidence from a panel of ten largest hydroelectricity consumers. Renewable And Sustainable Energy Reviews, 62, 318-325.

http://dx.doi.org/10.1016/j.rser.2016.04.075

Aubouin, J., \& Dercourt, J. (1962). Zone preapulienne, zone ionienne et zone du Gavrovo en Peloponnese occidental. Bulletin De La Société Géologique De France, 4(6), 785-794. http://dx.doi.org/10.2113/gssgfbull.S7-IV.6.785

Badr, M., Atallah, A., \& Bayoumi, M. (2016). Performance Analysis of SMES Integrated with Offshore Wind Farms to Power Systems through MT-HVDC. Indonesian Journal Of Electrical Engineering And Computer Science, 4(1), 1.

http://dx.doi.org/10.11591/ijeecs.v4.i1.pp1-9

Bringezu, S., Schütz, H., O’Brien, M., Kauppi, L., Howarth, R., \& McNeely, J. (2009). Towards sustainable production and use of resources: Assessing Biofuels. Paris: United Nations Environment Programme.

Chatzipanagiotou, M., Oikonomidis, D., \& Voudouris, K. (2015). Selection of MSW landfill site using G.I.S.: a case study in Zakynthos Island, Greece [in Greek]. In 10th International Congress of the Hellenic Geographical Society. Retrieved from https://goo.g1/4ARP1Y 


\section{Macrothink}

Environmental Management and Sustainable Development

ISSN 2164-7682 2018, Vol. 7, No. 1

Clément, A., McCullen, P., Falcão, A., Fiorentino, A., Gardner, F., \& Hammarlund, K. et al. (2002). Wave energy in Europe: current status and perspectives. Renewable And Sustainable Energy Reviews, 6(5), 405-431. http://dx.doi.org/10.1016/s1364-0321(02)00009-6

Cotton, C., Douglass, J., De Causmaecker, S., Brinkert, K., Cardona, T., \& Fantuzzi, A. et al. (2015). Photosynthetic Constraints on Fuel from Microbes. Frontiers In Bioengineering And Biotechnology, 3. http://dx.doi.org/10.3389/fbioe.2015.00036

Cristobal, J. (2014). Multi criteria analysis in the renewable energy industry. Springer London Ltd.

Demirbas, A. (2009). Political, economic and environmental impacts of biofuels: A review. Applied Energy, 86, S108-S117. http://dx.doi.org/10.1016/j.apenergy.2009.04.036

De-Viazi, S., Konomos, D. and Tsourakis, D. (1968). Paintings in Greece. Zakynthos: Mellon.

Diakoulaki, D., \& Karangelis, F. (2007). Multi-criteria decision analysis and cost-benefit analysis of alternative scenarios for the power generation sector in Greece. Renewable And Sustainable Energy Reviews, 11(4), 716-727. http://dx.doi.org/10.1016/j.rser.2005.06.007

Doerr, A. (1971). The Role of White Papers. In G. Doern \& P. Aucoin, The Structures of Policy-making in Canada. Toronto (pp. 179-203). Macmillan.

Ellabban, O., Abu-Rub, H., \& Blaabjerg, F. (2014). Renewable energy resources: Current status, future prospects and their enabling technology. Renewable And Sustainable Energy Reviews, 39, 748-764. http://dx.doi.org/10.1016/j.rser.2014.07.113

European Commission. (1996). Energy for the Future: Renewable Sources of Energy - Green Paper for a Community Strategy. COM (96), 576. Brussels: European Commission.

European Commission. (1997). Energy for the Future: Renewable Sources of Energy. White Paper for a Community Strategy and Action Plan. COM (97) 599. Brussels: European Commission.

European Commission. (2007). Communication from the Commission to the European Council and the European Parliament - An energy policy for Europe. [online] Retrieved from https://goo.gl/DHNrG1

European Commission. (2008). Climate change: Commission welcomes final adoption of Europe's climate and energy package. [online] Retrieved from https://goo.gl/yMfYTM

European Commission. (2011a). Communication from the Commission to the European Parliament, the council, the European economic and Social Committee and the Committee of the regions. Energy Roadmap 2050. [online] Retrieved from https://goo.gl/eUSSmW

European Commission. (2011b). Green Paper - Towards a European strategy for the security of energy supply. [online] Retrieved from https://goo.gl/WzdYZx [Accessed 26 Nov. 2017].

European Commission. (2017a). Policies, Information and Services. [online] Retrieved from 
https://ec.europa.eu

European Commission. (2017b). Regulations, Directives and other acts. [online] Retrieved from https://europa.eu

European Wind Energy Association. (2009). Wind energy - the facts. London: Earthscan. ISBN: 9781844077106

Field, C. (1998). Primary Production of the Biosphere: Integrating Terrestrial and Oceanic Components. Science, 281(5374), 237-240. http://dx.doi.org/10.1126/science.281.5374.237

Figueira, J., Greco, S., \& Ehrogott, M. (2005). Multiple Criteria Decision Analysis: State of the Art Surveys. International Series In Operations Research \& Management Science. http://dx.doi.org/10.1007/b100605

Gando, A., Gando, Y., Ichimura, K., Ikeda, H., Inoue, K., \& Kibe, Y. et al. (2011). Partial radiogenic heat model for Earth revealed by geoneutrino measurements. Nature Geoscience, 4(9), 647-651. http://dx.doi.org/10.1038/ngeo1205

Georganteas, N. (2011). Design, Environmental and Economic Analysis of a Hybrid Wind, Solar Energy and Diesel for the Energy Independence of the Islands. The Case of Astypalea [in Greek]. (Master of Science). National Technical University of Athens. Retrieved from https://goo.gl/NvxcWY

Giannakopoulos, M. (2015). Application of multi criteria decision making and spatial analysis to renewable energy development in GIS environment: The case of onshore wind farm in Zakynthos [in Greek]. (Engineering Diploma). National Technical University of Athens. Retrieved from https://goo.gl/G5gctT

Giatrakos, G., Tsoutsos, T., Mouchtaropoulos, P., Naxakis, G., \& Stavrakakis, G. (2009). Sustainable energy planning based on a stand-alone hybrid renewableenergy/hydrogen power system: Application in Karpathos island, Greece. Renewable Energy, 34(12), 2562-2570. http://dx.doi.org/10.1016/j.renene.2009.05.019

Global Wind Energy Council. (2017). Global Wind Statistics 2016. Global Wind Energy Council. Retrieved from https://goo.gl/KhpS4y

Greek Ministry of Environment and Energy. (2009). Greek National renewable energy action plan in the scope of the 2009/28/EC Directive. Athens: Greek Ministry of Environment and Energy.

Greek Ministry of Environment and Energy. (2010). Determination of an installed capacity future target among different renewable energy technologies for 2014 and 2020 [in Greek]. Athens: Greek Ministry of Environment and Energy.

Greek Ministry of Environment and Energy. (2014). 6th National communication and 1st biennial report under the United Nations Framework Convention on Climate Change. Athens: Greek Ministry of Environment and Energy.

Greek Ministry of Environment and Energy. (2017). Energy and Climate Change. [online] 
Retrieved from http://www.ypeka.gr

Guarte, J., \& Barrios, E. (2006). Estimation Under Purposive Sampling. Communications In Statistics - Simulation And Computation, 35(2), 277-284.

http://dx.doi.org/10.1080/03610910600591610

Habich, S. (2016). Reasons to Dam: China's Hydropower Politics and Its Socio-Environmental Consequences. Governance, Domestic Change, And Social Policy In China, 103-127. http://dx.doi.org/10.1057/978-1-137-02285-1_5

Hellenic Independent Power Transmission Operator. (2017a). Energy Data. [online] Retrieved from http://www.admie.gr

Hellenic Independent Power Transmission Operator. (2017b). Transmission System Description. [online] Retrieved from http://www.admie.gr

Hellenic National Meteorological Service. (2017). Climatology. [online] Retrieved from http://www.emy.gr

Hellenic Statistical Authority. (2017a). Statistics - Electric Power. [online] Retrieved from http://www.statistics.gr

Hellenic Statistical Authority. (2017b). Statistics - Population and Social Conditions. [online] Retrieved from http://www.statistics.gr

Hellenic Statistical Authority. (2017c). Statistics - Agriculture, Livestock, Fishery. [online] Retrieved from http://www.statistics.gr

Hellenic Statistical Authority. (2017d). Statistics - Economy, Indices. [online] Retrieved from http://www.statistics.gr

Howlett, M., \& Cuenca, J. (2016). The use of indicators in environmental policy appraisal: lessons from the design and evolution of water security policy measures. Journal of Environmental Policy \& Planning, 19(2), 229-243.

http://dx.doi.org/10.1080/1523908x.2016.1207507

Ithakisios, D. (1988). The economic development of the Island of Zakynthos: An historical Analysis from antiquity to the present [in Greek] (Ph.D.). University of Piraeus.

Johnson, D., Loss, S., Smallwood, K., \& Erickson, W. (2016). Avian fatalities at wind energy facilities in North America: a comparison of recent approaches. Human-Wildlife Interactions, 10(1), 7-18.

Kaldellis, K. (2005). Wind Energy Management [in Greek] (2nd ed.) Athens: Stamoulis Publications. ISBN: 9603515760

Kalimeris, A., Founda, D., Giannakopoulos, C., \& Pierros, F. (2011). Long-term precipitation variability in the Ionian Islands, Greece (Central Mediterranean): climatic signal analysis and future projections. Theoretical And Applied Climatology, 109(1-2), 51-72.

http://dx.doi.org/10.1007/s00704-011-0550-5 
Kelly-Richards, S., Silber-Coats, N., Crootof, A., Tecklin, D., \& Bauer, C. (2017). Governing the transition to renewable energy: A review of impacts and policy issues in the small hydropower boom. Energy Policy, 101, 251-264.

http://dx.doi.org/10.1016/j.enpol.2016.11.035

Keseru, I., Bulckaen, J., \& Macharis, C. (2016). The multi-actor multi-criteria analysis in action for sustainable urban mobility decisions: the case of Leuven. International Journal of Multicriteria Decision Making, 6(3), 211. http://dx.doi.org/10.1504/ijmcdm.2016.079713

Kiziroğlu, I., \& Erdogan, A. (2015). Relations between ecosystem and wind energy. Fresenius Environmental Bulletin, 24(1a), 163-171.

Konomos, D. (1964). Temples and Monasteries in Zakynthos. Athens: Ionian Bank of Greece.

Koronaios, C. (2012). Renewable energy sources: Teaching Notes [in Greek]. Lecture, National Technical University of Athens, Greece. Retrieved from https://goo.g1/ywuBx3

Kütting, G. (2010). The global political economy of the environment and tourism. Houndmills, Basingstoke, Hampshire: Palgrave Macmillan.

Li, K., Bian, H., Liu, C., Zhang, D., \& Yang, Y. (2015). Comparison of geothermal with solar and wind power generation systems. Renewable And Sustainable Energy Reviews, 42, 1464-1474. http://dx.doi.org/10.1016/j.rser.2014.10.049

Megalovasilis, P. (2014). A new hydrological balance and water management issues in Zakynthos Island, Greece. International Journal Of Hydrology Science And Technology, 4(2), 139. http://dx.doi.org/10.1504/ijhst.2014.066441

Megalovasilis, P., Kalimeris, A., Founda, D., \& Giannakopoulos, C. (2011). Climatic modelling and groundwater recharge affecting future water demands in Zakynthos Island, Ionian Sea, Greece. In N. Lambrakis, G. Stournaras \& K. Katsanou, Advances in the Research of Aquatic Environment. Environmental Earth Sciences. (pp. 99-107). Heidelberg: Springer. Retrieved from https://goo.gl/qgospo

Mitoula, R. (2007). Sustainable regional development in the European Union and reconstruction of Greek urban environment. Athens: Stamoulis Publications. ISBN: 9789603516705

Mitoula, R., Theodoropoulou, H., Karnabos, D., \& Apostolopoulos, K. (2012). Contribution of municipalities to the cities' sustainable physiognomy. recording local's opinions and perceptions. The case of kallithea. International Journal Of Sustainable Development And Planning, 7(3), 345-355. http://dx.doi.org/10.2495/sdp-v7-n3-345-355

Moomaw, W., Burgherr, P., Heath, G.,Lenzen, M., Nyboer, J., Verbruggen, A. (2011): Annex II: Methodology. In IPCC Special Report on Renewable Energy Sources and Climate Change Mitigation [O. Edenhofer, R. Pichs-Madruga, Y. Sokona, K. Seyboth, P. Matschoss, S. Kadner, T. Zwickel, P. Eickemeier, G. Hansen, S. Schlömer, C. von Stechow (eds)], Cambridge University Press, Cambridge, United Kingdom and New York, NY, USA. Retrieved from https://goo.gl/5Rx4Np 
Murthy, S., \& Hegde, S. (2017). Hydroelectricity. In M. Rashid, Electric Renewable Energy Systems (pp. 78-91). Elsevier. Retrieved from https://goo.g1/2xe5QM

Mylona, Z. (1998). The Zakynthos Museum. Athens: Archaeological Receipts Fund Direction of Publications.

National Marine Park of Zakynthos. (2017). Protected Areas. [online] Retrieved from http://www.nmp-zak.org/en

Niemeijer, D. (2002). Developing indicators for environmental policy: data-driven and theory-driven approaches examined by example. Environmental Science \& Policy, 5(2), 91-103. http://dx.doi.org/10.1016/s1462-9011(02)00026-6

Papaefthymiou, G., \& Dragoon, K. (2016). Towards 100\% renewable energy systems: Uncapping power system flexibility. Energy Policy, 92, 69-82.

http://dx.doi.org/10.1016/j.enpol.2016.01.025

Petris, T. (1978). Zakynthos: History, Art, Folklore, Modern Life [in Greek]. Athens: Toubis Publications

Pohekar, S., \& Ramachandran, M. (2004). Application of multi-criteria decision making to sustainable energy planning-A review. Renewable And Sustainable Energy Reviews, 8(4), 365-381. http://dx.doi.org/10.1016/j.rser.2003.12.007

Romitti, Y. (2015). The International Geothermal Market At a Glance. Geothermal Energy Association. Retrieved from https://goo.gl/RhheT7

Saaty, R. (1987). The analytic hierarchy process - what it is and how it is used. Mathematical Modelling, 9(3-5), 161-176. http://dx.doi.org/10.1016/0270-0255(87)90473-8

Sammon, P., \& Hirst, A. (2014). The Ionian Islands. Newcastle upon Tyne: Cambridge Scholars Publishing.

Sánchez-Lozano, J., García-Cascales, M., \& Lamata, M. (2014). Identification and selection of potential sites for onshore wind farms development in Region of Murcia, Spain. Energy, 73, 311-324. http://dx.doi.org/10.1016/j.energy.2014.06.024

Santos, I., Vieira, N., Tiago Filho, G., Barros, R., \& Souza, A. (2016). Simple modelling for maximum flow rates determination to be applied in economically feasible small hydropower plants. American Journal Of Hydropower, Water And Environment Sytems, 3, 11-13. http://dx.doi.org/10.14268/ajhwes.2016.00030

Sanyal, S., Morrow, J., Butler, S., \& Robertson-Tait, A. (2007). Cost of Electricity from Enhanced Geothermal Systems. In Thirty-Second Workshop on Geothermal Reservoir Engineering. Stanford, California: Stanford University. https://goo.gl/CkAGCQ

Sanz-Bobi, M. (2014). Use, Operation and Maintenance of Renewable Energy Systems. Cham: Springer International Publishing.

Smith, S., Meiners, S., Hastings, R., Thomas, T., \& Colombo, R. (2017). Low-Head Dam 
Impacts on Habitat and the Functional Composition of Fish Communities. River Research And Applications, 33(5), 680-689. http://dx.doi.org/10.1002/rra.3128

Solman, J. and Cox, G. (1991). Zakynthos, today and yesterday. Athens: Michalis Toumbis Editions S.A.

Sørensen, B. (2004). Renewable energy. Amsterdam: Elsevier Academic Press. ISBN: 9780126561531

Š́ri, M., Huld, T., Dunlop, E., \& Ossenbrink, H. (2007). Potential of solar electricity generation in the European Union member states and candidate countries. Solar Energy, 81(10), 1295-1305. http://dx.doi.org/10.1016/j.solener.2006.12.007

Swain, M., Lovering, J., Blomqvist, L., Nordhaus, T., \& Hernandez, R. (2015). Land-Use Intensity of Electricity Production: Comparison Across Multiple Sources. American Geophysical Union. Retrieved from https://goo.gl/gicjoH

Trainor, A., McDonald, R., \& Fargione, J. (2016). Energy Sprawl Is the Largest Driver of Land Use Change in United States. PLOS ONE, 11(9), e0162269.

http://dx.doi.org/10.1371/journal.pone.0162269

Triantaphyllou, E. (2000). Multi-criteria decision making methods. Boston, Mass: Kluwer Academic Publishers.

Tsirika, A., \& Haritonidis, S. (2005). A survey of the benthic flora in the National Marine Park of Zakynthos (Greece). Botanica Marina, 48(1). http://dx.doi.org/10.1515/bot.2005.002

Tsirika, A., Skoufas, G., \& Haritonidis, S. (2007). Seasonal and bathymetric variations of epiphytic macroflora on Posidonia oceanica (L.) Delile leaves in the National Marine Park of Zakynthos (Greece). Marine Ecology, 28, 146-153.

http://dx.doi.org/10.1111/j.1439-0485.2007.00170.x

Tsoutsos, T., Drandaki, M., Frantzeskaki, N., Iosifidis, E., \& Kiosses, I. (2009). Sustainable energy planning by using multi-criteria analysis application in the island of Crete. Energy Policy, 37(5), 1587-1600. http://dx.doi.org/10.1016/j.enpol.2008.12.011

Türkay, B., \& Telli, A. (2011). Economic analysis of standalone and grid connected hybrid energy systems. Renewable Energy, 36(7), 1931-1943.

http://dx.doi.org/10.1016/j.renene.2010.12.007

Tzivara, P. (2009). Venetian Zante 1588-1594. The distribution of power by the Council of the 150. Athens: Enalios.

Tzouvelekis, A. (2014). A study of the potential for small wind turbines in Greece: Current market status, barriers to growth and support policy options (Master of Science). Delft University of Technology. Retrieved from https://goo.gl/QmpqEf

Urban, F., \& Mitchell, T. (2011). Climate change, disasters and electricity generation. Strengthening Climate Resilience Institute of Development Studies, University of Sussex, Brighton, UK. Retrieved from https://goo.gl/xmvUX6 


\section{Macrothink}

Vardopoulos, I. (2017). Multi-criteria Analysis for Energy Independence from Renewable Energy Sources Case Study Zakynthos Island, Greece. International Journal Of Environmental Science And Development, 8(6), 460-465.

http://dx.doi.org/10.18178/ijesd.2017.8.6.997

Vasileiadis, C. (2015). Techno-economical study, dimensioning and study of the permanent and transient hybrid electric power system on the island of Gavdos [in Greek] (Bachelor of Engineering). University of Patras. Retrieved from https://goo.gl/wZzcgU

Wang, J., O'Donnell, J., \& Brandt, A. (2017). Potential solar energy use in the global petroleum sector. Energy, 118, 884-892. http://dx.doi.org/10.1016/j.energy.2016.10.107

Whittaker, J. (2002). Zakynthos and the European revolution, 1797-1821. Napoli: Istituto universitario orientale, Dipartimento di studi dell'Europa orientale.

Wiser, R., Bolinger, M., Heath, G., Keyser, D., Lantz, E., \& Macknick, J. et al. (2016). Long-term implications of sustained wind power growth in the United States: Potential benefits and secondary impacts. Applied Energy, 179, 146-158.

http://dx.doi.org/10.1016/j.apenergy.2016.06.123

Zarkadi, D. (2009). Tourism as an economic foundation keystone of the Ionian Islands development. The case of Zakynthos Island (Master of Science). Panteion University of Social and Political Sciences.

Zervanos, L. (2015). Singing in Greek: A Guide to Greek Lyric Diction and Vocal Repertoire. London: Rowman \& Littlefield.

Zivas, D. (1984). Zakynthos Architecture. Athens: Technical Chamber of Greece.

\section{Copyright Disclaimer}

Copyright for this article is retained by the author(s), with first publication rights granted to the journal.

This is an open-access article distributed under the terms and conditions of the Creative Commons Attribution license (http://creativecommons.org/licenses/by/3.0/). 